\section{Estudo \\ Ecidebate}

em Testão

Plamejamento
Revista Estudo \& Debate, Lajeado, v. 25, n. 3, 2018. ISSN 1983-036X

DOI: http://dx.doi.org/10.22410/issn.1983-036X.v25i3a2018.1717

\title{
PLANEJAMENTO TRIBUTÁRIO: CONTRIBUIÇÓES AO GERENCIAMENTO DE TRIBUTOS EM UMA EMPRESA DE VENDAS E LOCAÇÃO DE EQUIPAMENTOS DE INFORMÁTICA
}

\author{
Andréia Bicioni Pacheco Dourado ${ }^{1}$, Sofia Ines Niveiros ${ }^{2}$, Ramon Luiz Arenhardt ${ }^{3}$, \\ Aloisio Rodrigues Da Silva ${ }^{4}$, José Ribeiro Viana Filho ${ }^{5}$
}

\begin{abstract}
Resumo: A finalidade central desta pesquisa é demonstrar a importância do planejamento tributário como um processo que possibilita a escolha da melhor opção de regime tributário, visando a economia de tributos, dever constitucional de todo administrador ativo e probo. As empresas buscam por meio legal e até mesmo como dever dos gestores identificar as possibilidades regulamentares de reduzir a carga tributária e com isso aumentar a capacidade competitiva e de sobrevivência de seus negócios, por meio de açôes oriundas do planejamento tributário, enquanto processo de gestáo de tributos. O planejamento tributário é um processo contínuo dentro de qualquer atividade de negócios. Enquanto de um lado o contribuinte busca identificar algumas situaçôes que possibilitam reduzir seus custos com tributos, por outro o fisco está sempre atento para eliminar qualquer possibilidade de evasáo de tributos. Foi realizado um levantamento dos dados da empresa por meio dos relatórios contábeis. Destacando a importância do planejamento tributário esta pesquisa se propôs a responder à seguinte questáo: Como o planejamento tributário pode auxiliar na definição do regime tributário com o foco de reduzir a carga tributária da empresa estudada? O estudo foi desenvolvido a partir de uma pesquisa descritiva e qualitativa, os dados foram coletados por meio dos relatórios contábeis da empresa que é enquadrada no regime do Simples Nacional. O período analisado foram os anos de 2014 e 2015. Os resultados obtidos pela análise comparativa dos dados evidenciados em suas demonstraçóes contábeis apresentam que o regime de tributação adotado pela empresa atualmente é o mais favorável e que o planejamento tributário contribui efetivamente para a definição do regime mais vantajoso para a empresa analisada.
\end{abstract}

Palavras-chave: Planejamento Tributário. Prestação de Serviços. Regimes de Tributação.

1 Graduação em Ciências Contábeis pela UFMT.

2 Graduação em Ciências Contábeis pela UFSC. Doutora em Engenharia de Produção pela UFSC. Docente da Universidade Federal de Mato Grosso/CIC/ICHS/CUR.

3 Graduação em Ciências Contábeis pela UFMT. Doutorando em Administração pela UNINOVE. Docente da Universidade Federal de Mato Grosso/CIC/ICHS/CUR.

4 Graduação em Ciências Contábeis pela UFMT. Doutor em Ciências Contábeis pela UNR. Docente da Universidade Federal de Mato Grosso/CIC/ICHS/CUR.

5 Graduação em Ciências Contábeis pela UFMT. Mestre em Ciências Contábeis pela UFPB. Docente da Universidade Federal de Mato Grosso/CIC/ICHS/CUR. 


\title{
TAX PLANNING: REDUCTION OF TAXES IN A COMPANY OF SALES OF LEASING OF COMPUTER EQUIPMENT IN THE MUNICIPALITY OF RONDONÓPOLIS-MT.
}

\begin{abstract}
The main purpose of this research is to demonstrate the importance of tax planning as a process that allows the choice of the best tax regime option, aiming at tax savings, constitutional duty of all active and probo. The companies seek by legal means and even as a duty of managers to identify the regulatory possibilities of reducing the tax burden and thereby increase the competitive and survival capacity of their businesses, through actions arising from tax planning, as a process of management of tributes. Tax planning is an ongoing process within any business activity. While on the one hand the taxpayer seeks to identify some situations that make it possible to reduce their costs with taxes, on the other, the tax authorities are always attentive to eliminate any possibility of tax evasion. A survey of the company's data was performed through the accounting reports. Emphasizing the importance of tax planning, this research proposed to answer the following question: How can tax planning help in defining the tax regime that reduces the tax burden of the company studied? The study was developed from a descriptive and qualitative research, the data were collected through the accounting reports of the company that is framed in the regime of National Simples. The period analyzed was the years 2014 and 2015. The results obtained by the comparative analysis of the data evidenced in its financial statements show that the tax regime adopted by the company is currently the most favorable and that tax planning effectively contributes to the definition of the regime more advantageous for the company analyzed.
\end{abstract}

Keywords: Tax Planning. Services. Taxation.

\section{Introdução}

Aportar caminhos, por intermédio do conhecimento dos negócios realizados pelo contribuinte, é papel fundamental do planejamento tributário enquanto processo que incluiu açóes seguras e legais de redução de custos, inclusive com tributos. Disso, surge a gestão tributária, que pode fornecer grande vantagem competitiva empresarial, criando oportunidades para novos investimentos e maiores resultados (SANTOS, 2012).

O planejamento tributário torna-se indispensável para as empresas que buscam de forma legal maneiras para pagar menos tributos e consequentemente obter mais lucros. $\mathrm{O}$ planejamento é realizado para verificar principalmente se o regime de tributação adotado pela empresa é o mais adequado para ela (MUNIZ, 2012).

O processo de redução da carga tributária pode ser feito de duas formas: a lícita que é denominada elisão fiscal e a ilícita conhecida como sendo evasão fiscal. A elisão fiscal é feita por meio de planejamento fiscal buscando brechas nas leis para poder reduzir a carga tributária de forma legal, bem como definir o melhor momento para o pagamento de cada tributo, por meio da análise da ocorrência de seus fatos geradores, sem causar nenhum ônus. Já a evasão fiscal ocorre de forma totalmente ilegal, podendo assim causar ônus posteriormente se for comprovada essa ilegalidade (MUNIZ, 2012; SANTOS, 2012).

No ambiente tributário do Brasil existem quatro regimes disponíveis na sistemática de apuração de tributos que são: Simples Nacional, Lucro Presumido, Lucro Real e Lucro Arbitrado. Esta pesquisa compreende a análise do melhor regime de apuração para a empresa estudada, apresentando os aspectos conceituais e informaçóes obtidas junto aos gestores, por meio de relatórios fiscais e contábeis fornecidos pelo serviço de contabilidade. Ao discorrerem sobre a finalidade da contabilidade tributária Chaves e Muniz (2016, p. 3) 
assim expressam: "A contabilidade registra os fatos geradores de tributos na pessoa jurídica, como também fatos econômicos que não geram tributos e outros que têm reflexos indiretos na carga tributária da empresa”.

O planejamento tributário é a forma lícita de reduzir a carga fiscal das empresas, exigindo conhecimento, estratégias e informaçóes, o seu propósito é encontrar a alternativa legal com menos custos para o contribuinte; ou seja, a tributação que melhor se enquadra com a atividade da empresa (GOLLUB, 2015).

É oportuno enfatizar que o enquadramento adequado do regime de tributação proporcionará a maximizaçáo de resultados e em decorrência desse efeito o planejamento tributário, contribuirá para o aumento da competitividade da organização de negócios, bem como para a sua permanência no mercado gerando emprego e renda.

Com base nos levantamentos realizados e destacando à importância do planejamento tributário para a empresa do ramo de vendas e locaçáo de produtos informática, em questão, atualmente enquadrada no Simples Nacional, buscou-se resposta ao seguinte questionamento: Como o planejamento tributário pode auxiliar na definição do regime tributário com o foco de reduzir a carga tributária da empresa estudada?

Este trabalho se justifica por contribuir à empresa estudada, com resultados que proporcionarão informaçóes aos gestores, as quais servirão de instrumentos de avaliação de desempenho da empresa, auxiliando no processo de tomada de decisão, especialmente em relação ao tipo de tributação adotada pela empresa. Outro eixo que justifica este trabalho é que ele servirá de estímulo aos gestores da empresa, no que diz respeito aos resultados alcançados e, além disso, poderá instigá-los a desenvolver um controle periódico dos resultados e leva-los a sempre realizar analise dos resultados obtidos pela empresa.

O objetivo geral do estudo é demonstrar a importância do planejamento tributário como um processo que possibilita a escolha da melhor opção de regime tributário, visando a economia de tributos, dever constitucional de todo administrador ativo e probo.

No estudo parte-se do pressuposto que o regime tributação adotado pela empresa que atualmente é o Simples Nacional, seja a forma de se economizar no recolhimento dos impostos, visto que a empresa é de pequeno porte, e ser prestadora de serviços, tendo assim baixo custo operacional.

\section{Fundamentaçáo Teórica}

Neste tópico as temáticas contempladas são Planejamento e Contabilidade Tributária; Regimes de Tributação; Empresas Prestadoras de Serviço; Principais Tributos incidentes nas empresas prestadoras de Serviço e Trabalhos realizados relacionados ao tema da pesquisa.

\subsection{Planejamento e Contabilidade Tributária}

A carga tributária brasileira tem se mostrado cada vez mais elevada atualmente existem vários tributos diferentes divididos entre taxas, impostos e contribuiçóes, todos exigidos por lei nas três esferas de governo: Federal, Estadual e Municipal (SILVA et al., 2011). 
Contabilidade Tributária é definida por Fabretti (2014, p. 5) como sendo: “[...] o ramo da contabilidade que tem por objetivo aplicar na pratica conceitos, princípios e normas básicas da contabilidade e da legislação tributária, de forma simultânea e adequada". Por outro lado, para que a contabilidade tributária possa servir de suporte básico para a elaboração do planejamento tributário deve considerar aos seguintes aspectos fundamentais:

a) adequado planejamento tributário (que exige conhecimento da legislação tributária);

b) relatórios contábeis eficazes que demonstrem a exata situação das contas do patrimônio e do resultado (que exige conhecimento de contabilidade);

c) controle apurado das despesas indedutíveis e das receitas náo tributáveis, temporárias ou definitivas para apuração da base de cálculo dos tributos. (FABRETTI, 2014, p, 37).

Tendo em vista os conceitos relativos a contabilidade tributaria, pode se dizer que ela é responsável pela verificação e validação dos tributos incidentes na empresa. A partir de então, faz se necessário a realização do planejamento tributário como uma ferramenta para obter a economia fiscal. ZANLUCA (2012) apresenta que:

O planejamento tributário é um conjunto de sistemas legais que visam diminuir o pagamento de tributos. O contribuinte tem o direito de estruturar o seu negócio da maneira que melhor lhe pareça, procurando a diminuiçấo dos custos de seu empreendimento, inclusive dos impostos. Se a forma celebrada é jurídica e lícita, a fazenda pública deve respeitá-la. (ZANLUCA, 2012).

\section{Já Fabretti conceitua Planejamento Tributário como:}

Estudo feito preventivamente, ou seja, antes da realização do fato administrativo, pesquisando-se seus efeitos jurídicos e econômicos e as alternativas legais menos onerosas, denomina-se Planejamento Tributário.

O Planejamento Tributário exige, antes de tudo, bom senso do planejador.

Há alternativas legais válidas para grandes empresas, mas que são inviáveis para as médias e pequenas, dado o custo das operaçóes necessárias para execuçáo desse planejamento podem exigir.

A relação custo/benefício deve ser muito bem avaliada. Não há mágica em planejamento tributário, apenas alternativas, cujas relaçóes custo/benefício variam muito em função dos valores envolvidos, da época, do local etc [...] (FABRETTI, 2009, p. 8).

Dessa forma os empresários podem estruturar o seu negócio da forma mais competitiva, respeitando as leis brasileiras. Este entendimento se apoia a conhecida elisão fiscal ou economia legal (planejamento tributário).

A elisão fiscal pressupõe a licitude de comportamento do contribuinte que objetive identificar as consequências fiscais de uma decisão, resultando em uma economia de tributos [...] pode ser definida como todo procedimento lícito realizado pelo contribuinte antes da ocorrência do fato gerador com o objetivo de eliminar ou postergar a obrigação tributária ou reduzir o montante devido. (OLIVEIRA; 2009, p.193). 
Dentre as formas mais utilizadas de elisão fiscal a mais utilizada é o regime tributário, através do planejamento tributário se chega a melhor opção para cada entidade. Sem que ela seja prejudicada.

\subsection{Regimes de Tributação}

No Brasil há pelo menos quatro possibilidades de opção tributária para o cálculo e pagamento do imposto de renda e da contribuição social sobre o lucro e em decorrência da opção escolhida o cálculo de outros tributos como por exemplo o PIS e a COFINS. Neste tópico são discutidos os seguintes regimes de tributação: Lucro Real, Lucro Presumido, Lucro Arbitrado e Simples Nacional.

\subsubsection{Lucro Real}

De acordo com o Decreto no 3000/1999, atualizado pela Lei no $12.973 / 2014$, o Lucro Real é conceituado como sendo o resultado contábil líquido do trimestre antes do IRPJ e CSLL, transcrito em livro próprio - denominado Livro de Apuração do Lucro Real Eletrônico (E-LALUR) e (E-LACS) Livro de Apuração de Contribuição Social. Todos ajustados pelas adiçóes, exclusóes e compensaçóes prescritas ou autorizadas pela legislação do imposto de renda. Precisamente, o art. 247, do Decreto no 3000/99 assim o conceitua: 囚Lucro real é o lucro líquido do período de apuração ajustado pelas adições, exclusóes ou compensaçóes prescritas ou autorizadas por este Decreto (Decreto-Lei nº 1.598, de 1977, art. $\left.6^{\circ}\right)$.

Fabretti conceitua Lucro real como:

Lucro real é um conceito fiscal e não econômico. No conceito econômico, o lucro é o resultado positivo da soma algébrica de receita bruta (de vendas ou serviços) (-) devoluçóes e impostos (-) custos (-) despesas operacionais (+) receitas não operacionais (-) despesas não operacionais. Ou seja, o resultado contábil. A Lei do IR denomina esse resultado contábil (econômico) de lucro líquido.

O lucro real, conforme determina o art. 247 do RIR, é o lucro líquido (contábil) do período-base ajustado pelas adiçóes, exclusóes ou compensaçóes prescritas ou autorizadas pela legislação do IR.

Logo, o lucro real para uma apuração eminentemente fiscal é, na prática, para dizer o menos, inadequada.

Real dá a ideia de verdadeiro, que no caso, é o resultado econômico positivo - receita maior do que despesa.

$\mathrm{Na}$ prática, verifica-se que às vezes, a empresa tem um resultado econômico negativo (prejuízo), mas a legislação do IR manda adicionar a ele diversos valores que considera não dedutíveis.

Assim, de um prejuízo econômico - resultado econômico, contábil, verdadeiro - apura-se um "lucro real" mediante a adiçáo de despesas ao resultado negativo, tornando-o positivo. Nada mais irreal. (FABRETTI, 2009, p.202).

O Decreto no 3.000 traz o seguinte conceito sobre o lucro real: 
Art. 247. Lucro real é o lucro líquido do período de apuração ajustado pelas adições, exclusôes ou compensaçôes prescritas ou autorizadas por este Decreto (Decreto-Lei $\mathrm{n}^{\circ}$ 1.598 , de 1977 , art. $6^{\circ}$ ).

$\$ 1^{\circ}$ A determinação do lucro real será precedida da apuraçáo do lucro líquido de cada período de apuração com observância das disposiçôes das leis comerciais (Lei no 8.981 , de 1995 , art. $\left.37, \$ 1^{\circ}\right)$.

$\$ 2^{\circ}$ Os valores que, por competirem a outro período de apuração, forem, para efeito de determinação do lucro real, adicionados ao lucro líquido do período de apuração, ou dele excluídos, serão, na determinação do lucro real do período de apuração competente, excluídos do lucro líquido ou a ele adicionados, respectivamente, observado o disposto no parágrafo seguinte (Decreto-Lei $\mathrm{n}^{\circ} 1.598$, de 1977 , art. $6^{\circ}, \$ 4^{\circ}$ ).

$\$ 33^{\circ}$ Os valores controlados na parte "B" do Livro de Apuração do Lucro Real - LALUR, existentes em 31 de dezembro de 1995, somente serão atualizados monetariamente até essa data, observada a legislação então vigente, ainda que venham a ser adicionados, excluídos ou compensados em períodos de apuraçáo posteriores (Lei $\mathrm{n}^{\circ}$ 9.249, de 1995, art. 6º). (Decreto no 300, Seçấo III Art. 247 de 26 de março de 1999).

Comparando os conceitos acima as empresas optantes pelo regime de apuraçáo do Lucro Real irão apurar do imposto de renda e contribuição social sobre o lucro líquido, após realizadas todas adiçōes e exclusões. A alíquota para pagamento de IRPJ é de $15 \%$ e a CSLL normalmente é de $9 \%$, ambos calculados sobre o lucro real apurado. Podendo ser apuraçáo trimestral ou mensal com ajuste anual.

\subsubsection{Lucro Presumido}

O Lucro Presumido trata de uma tributação simplificada para determinação da base de cálculo do imposto de renda e da Contribuição Social Sobre o Lucro Líquido - CSLL das pessoas jurídicas. A sistemática é utilizada para presumir o lucro da pessoa jurídica a partir de sua receita bruta e outras receitas sujeitas à tributação. Segundo Fabretti, o Lucro Presumido:

É uma alternativa para as pequenas empresas, até o limite da receita bruta total estabelecido em lei. Estas, em vez de apuração pelo lucro real, ou seja, de escrituração contábil, podem presumir esse lucro. Consideram, como tal, o resultado da aplicaçáo de determinado percentual sobre a receita total (por exemplo: $8 \%$ de uma receita de $\mathrm{R} \$ 100.000,00=$ lucro presumido de $\mathrm{R} \$ 8.000,00)$. FABRETTI $(2009$, p. 202)

As pessoas jurídicas de direito privado, e as que lhe são equiparadas pela legislação do imposto de renda, que apuram o IRPJ com base no Lucro Presumido ou Arbitrado estão sujeitas à incidência cumulativa para PIS e COFINS.

A partir de 01.01.2014, o limite de receita bruta total passou a ser $\mathrm{R} \$ 78.000 .000,00$ (setenta e oito milhões de reais) ou a $\mathrm{R} \$$ 6.500.000,00 (seis milhôes e quinhentos mil reais) multiplicados pelo número de meses de atividade do ano-calendário anterior, quando inferior a 12 (doze) meses, poderá optar pelo regime de tributaçáo com base no lucro presumido (Lei 12.814/2013, Art. 7).

Conforme citado na Lei 9.430/1996, Art. 26 a opção pela tributação com base no Lucro Presumido terá aplicaçáo sobre todo o período de atividade da empresa em cada ano 
calendário e será manifestada após o pagamento da primeira ou única quota do imposto pertinente ao primeiro período de apuração (BRASIL, 1996).

No regime do lucro presumido, a apuração do imposto será feita trimestralmente, por períodos encerrados em 31 de março, 30 de junho, 30 de setembro e 31 de dezembro de cada ano-calendário.

Desde 1999 a opção pela tributação com base no lucro presumido é definitiva em relação a todo o ano-calendário (Lei $9.718 / 1998$, artigo $13, \S 1^{\circ}$ ). Isso significa que as empresas optantes que efetuarem o pagamento no primeiro trimestre deverão permanecer nesse regime tributário durante todo o ano. (BRASIL, 1988).

O imposto com base no lucro presumido será determinado trimestralmente por períodos encerrados em 31 de março, 30 de junho, 30 de setembro e 31 de dezembro de cada ano-calendário (Lei 9.430/1996, artigos $1^{\circ}$ e 25, BRASIL, 1988 e RIR/1999, art. 516, $\left.\$ 5^{\circ}\right)$.

O IRPJ e a CSLL devidos com base no Lucro Presumido deverão ser pagos até o último dia útil do mês subsequente ao do encerramento do período de apuração trimestral.

\subsubsection{Lucro Arbitrado}

A respeito deste regime tributário é oportuno ressaltar que até o exercício social de 1995, pelas diretrizes da Lei $n^{\circ}$ 8.981, somente o fisco poderia arbitrar o resultado. Entretanto, conforme muito bem afirma Chaves (2017, p. 20) “[...] a partir de 1996, o contribuinte passou a fazer a opção, também por essa modalidade de base de cálculo do Imposto de Renda”. Isso em função da regulamentação do art. 26, da Lei no 8981/95, pelo art. 530 do Regulamento do Imposto de Renda que assim estabelece:

Art. 530. O imposto, devido trimestralmente, no decorrer do ano-calendário, será determinado com base nos critérios do lucro arbitrado, quando (Lei n ${ }^{\circ} 8.981$, de 1995, art. 47, e Lei $\mathrm{n}^{\circ} 9.430$, de 1996 , art. $1^{\circ}$ ):

III - o contribuinte deixar de apresentar à autoridade tributária os livros e documentos da escrituração comercial e fiscal, ou o Livro Caixa, na hipótese do parágrafo único do art. 527 ;

VI - o contribuinte não mantiver, em boa ordem e segundo as normas contábeis recomendadas, Livro Razão ou fichas utilizadas para resumir e totalizar, por conta ou subconta, os lançamentos efetuados no Diário.

Observa-se, então, que o contribuinte goza da liberdade em arbitrar o lucro para fins de determinar o imposto de renda e a contribuiçáo social, quando não dispor de documentação comprobatória para apresentar ao fisco, desde que disponha de elementos adequados para comprovar a origem de suas receitas.

Segundo Fabretti o Lucro Arbitrado:

É uma faculdade do fisco, prevista para os casos em que a pessoa jurídica não mantém escrituração na forma das leis comerciais e fiscais; deixa de elaborar as respectivas demonstraçóes financeiras; tem sua escrituração desclassificada pela fiscalização; optou indevidamente pela tributação com base no lucro presumido ou, ainda, se não mantém 
arquivo de documentos. Em qualquer dessas hipóteses, o fisco poderá arbitrar o lucro, cujas regras de arbitramento estão tornando-se cada vez mais severas. A autoridade tributária poderá fixar o lucro arbitrado por um percentual sobre a receita bruta, quando conhecida, ou com base no valor do ativo, do capital social, do patrimônio líquido, da folha de pagamento de empregados, das compras, do aluguel das instalaçóes ou do lucro líquido auferido em anos-calendários anteriores. $\mathrm{O}$ arbitramento não exclui a aplicação de penalidades cabíveis. (FABRETTI 2009, p.202)

De acordo com o art. 16 da Lei 9.249, de 26 de dezembro de 1995, o lucro arbitrado será determinado mediante:

O lucro arbitrado das pessoas jurídicas será determinado mediante a aplicação, sobre a receita bruta, quando conhecida, dos percentuais fixados no art. 15, acrescidos de vinte por cento. Parágrafo único. No caso das instituiçóes a que se refere o inciso III do art. 36 da Lei no 8.981, de 20 de janeiro de 1995 , o percentual para determinaçáo do lucro arbitrado será de quarenta e cinco por cento.

Sendo assim quando a empresa náo apresenta os fatos reais da empresa as autoridades fiscais podem arbitrar o lucro da empresa.

\title{
2.2.4 Simples Nacional
}

O Simples Nacional consiste em um sistema de tributação diferenciado, simplificado e favorecido, que consolida, em um único recolhimento, diversos tributos federais (IRPJ, CSL, PIS, COFINS, IPI e contribuição previdenciária patronal), estaduais (ICMS) e municipais (ISS), facilitando a vida das microempresas e das empresas de pequeno porte. A Lei Complementar no 123, da Receita Federal do Brasil explica que o Simples Nacional:

\begin{abstract}
Abrange a participação de todos os entes federados (União, Estados, Distrito Federal e Municípios). É administrado por um Comitê Gestor composto por oito integrantes: quatro da Secretaria da Receita Federal do Brasil (RFB), dois dos Estados e do Distrito Federal e dois dos Municípios. (LC 123)
\end{abstract}

Para o ingresso no Simples Nacional é necessário enquadrar-se na definição de microempresa ou de empresa de pequeno porte; cumprir os requisitos previstos na legislaçáo e formalizar a opçáo pelo Simples Nacional.

Características principais do Regime do Simples Nacional de acordo com a Lei Complementar 123/2006:

- ser facultativo;

- ser irretratável para todo o ano-calendário;

- abrange os seguintes tributos: IRPJ, CSLL, PIS/Pasep, Cofins, IPI, ICMS, ISS e a Contribuição para a Seguridade Social destinada à Previdência Social a cargo da pessoa jurídica (CPP);

- recolhimento dos tributos abrangidos mediante documento único de arrecadação

- disponibilização às ME/EPP de sistema eletrônico para a realização do cálculo do valor mensal devido, geração do DAS e, a partir de janeiro de 2012, para constituição do crédito tributário;

- apresentação de declaração única e simplificada de informações socioeconômicas e fiscais; 
- prazo para recolhimento do DAS até o dia 20 do mês subsequente àquele em que houver sido auferida a receita bruta;

- possibilidade de os Estados adotarem sublimites para EPP em função da respectiva participaçáo no PIB. Os estabelecimentos localizados nesses Estados cuja receita bruta total extrapolar o respectivo sublimite deveráo recolher o ICMS e o ISS diretamente ao Estado ou ao Município. (BRASIL, 2006).

O recolhimento do simples em uma guia única e os percentuais variam de acordo com a média acumulada nos últimos doze meses, os impostos estâo destacados todos na guia única de recolhimento do simples. Para saber quando irá se pagar de cada imposto a empresa tem que saber qual anexo da lei ela se enquadra, esses anexos podem ser encontrados no final da LC 123/2006.

\subsection{Empresas Prestadoras de Serviço}

Prestação de Serviços pode ser compreendida como a execuçáo de um trabalho contratado por terceiros (empresa/comunidade), que desempenhe quaisquer atividades materiais, ou intelectuais, com fim produtivo ou lucrativo.

Conforme citado por Maximiano (2011), os resultados da prestação de serviço são comprados pelos clientes por causa de sua utilidade. Essa ideia ajuda o empresário a pensar nas razóes que o cliente tem para adquirir o produto ou serviço e, ao mesmo tempo, nas medidas internas de eficiência da empresa. A prestação de Serviço é um sistema que possui entrada, que é a necessidade do cliente, o processamento é a prestação do serviço e a saída é a satisfação do cliente (MAXIMIANO, 2011).

\subsection{Principais Tributos incidentes nas empresas prestadoras de Serviço}

Neste tópico será relacionado os principais tributos incidentes em empresas prestadoras de serviços. Vamos destacar os de maior impacto nos três tipos de tributação: o Imposto de Renda, a Contribuiçấo Social Sobre o Lucro Líquido, a Contribuiçâao Para Financiamento Da Seguridade Social, o Programa De Integração Social e o Imposto Sobre Serviços de Qualquer Natureza.

\subsubsection{IR - Imposto de Renda}

O Imposto Sobre a Renda é de competência da União (federal), e incide sobre a renda tanto de físicas como jurídicas. A receita federal do Brasil trata como contribuintes:

\footnotetext{
São contribuintes e, portanto, estão sujeitos ao pagamento do IRPJ, as pessoas jurídicas e as pessoas físicas a elas equiparadas, domiciliadas no País. Elas devem apurar o IRPJ com base no lucro, que pode ser real, presumido ou arbitrado. A alíquota do IRPJ é de $15 \%$ (quinze por cento) sobre o lucro apurado, com adicional de $10 \%$ sobre a parcela do lucro que exceder R\$20.000,00 / mês. (RFB, 2016).
}

O Código Tributário Nacional (2010) traz alguns conceitos fundamentais no tange a forma de aplicação do mesmo. 
Art. 43. O imposto, de competência da União, sobre a renda e proventos de qualquer natureza tem como fato gerador a aquisição da disponibilidade econômica ou jurídica: I - de renda, assim entendido o produto do capital, do trabalho ou da combinaçáo de ambos;

II - de proventos de qualquer natureza, assim entendidos os acréscimos patrimoniais náo compreendidos no inciso anterior.

$\$ 1$ o A incidência do imposto independe da denominaçáo da receita ou do rendimento, da localização, condição jurídica ou nacionalidade da fonte, da origem e da forma de percepção. (Incluído pela Lcp no 104, de 2001)

$\$ 2$ o Na hipótese de receita ou de rendimento oriundos do exterior, a lei estabelecerá as condiçôes e o momento em que se dará sua disponibilidade, para fins de incidência do imposto referido neste artigo. (Incluído pela Lcp no 104, de 2001)

Art. 44. A base de cálculo do imposto é o montante, real, arbitrado ou presumido, da renda ou dos proventos tributáveis.

Art. 45. Contribuinte do imposto é o titular da disponibilidade a que se refere o artigo 43, sem prejuízo de atribuir a lei essa condição ao possuidor, a qualquer título, dos bens produtores de renda ou dos proventos tributáveis.

Parágrafo único. A lei pode atribuir à fonte pagadora da renda ou dos proventos tributáveis a condiçấo de responsável pelo imposto cuja retenção e recolhimento lhe caibam. (CNT, 2010).

O Imposto Sobre a Renda incide independentemente da forma de tributação da empresa, seja pelo Simples Nacional, Lucro Real ou Lucro Presumido. O que muda são os percentuais aplicados em cada tipo.

No Lucro Presumido é determinado por períodos de apuração trimestrais. Os percentuais aplicados para compor a base de cálculo do imposto de reanda do lucro presumido são localizados no art. 223 do RIR/1999, na Tabela abaixo está relacionado os percentuais:

Tabela 1 - Percentuais de presunção do IRPJ no lucro presumido

\begin{tabular}{l|c}
\hline Ramo/Atividades & $\%$ \\
\hline Atividades em geral (RIR/1999, art. 518) & 8,0 \\
\hline Revenda de combustíveis & 1,6 \\
\hline Serviços de transporte (exceto o de carga) & 16,0 \\
\hline Serviços de transporte de cargas & 8,0 \\
\hline Serviços em geral (exceto serviços hospitalares) & 32,0 \\
\hline $\begin{array}{l}\text { Serviços hospitalares e de auxílio diagnóstico e terapia, patologia clínica, imagenologia, } \\
\text { anatomia patológica e cito patológica, medicina nuclear e análises e patologias clínicas. }\end{array}$ & 8,0 \\
\hline Intermediação de negócios & 32,0 \\
\hline Administração, locação ou cessão de bens e direitos de qualquer natureza (inclusive imóveis). & 32,0 \\
\hline
\end{tabular}

Fonte: RFB (2016).

A Tabela 1 mostra os percentuais de acordo com o ramo de atividade de cada categoria. E tem uma variação na presunção que vai de 1,6\% até no máximo de 32\%. 
Já no lucro real independente do ramo de atividade o imposto de renda à alíquota de $15 \%$, incidente sobre a base de cálculo apurada. Essa apuraçáo pode ser anual, trimestral ou por estimativa mensal.

No Simples Nacional todos os impostos sáo recolhidos de forma única na guia do Simples, e varia de acordo o faturamento acumulado nos últimos 12 meses.

\subsubsection{CSLL - Contribuição Social Sobre o Lucro Liquido}

A Contribuição Social Sobre o Lucro Líquido foi instituído pela Lei no 7.689/98, e é de competência da União. Os contribuintes são as pessoas jurídicas domiciliadas no Brasil, e a mesma é equiparada pela legislação do Imposto de Renda. Para a RFB:

Estáo sujeitas ao pagamento da CSLL as pessoas jurídicas e as pessoas físicas a elas equiparadas, domiciliadas no País. A alíquota da CSLL é de 9\% (nove por cento) para as pessoas jurídicas em geral, e de 15\% (quinze por cento), no caso das pessoas jurídicas consideradas instituiçóes financeiras, de seguros privados e de capitalização. A apuração da CSLL deve acompanhar a forma de tributação do lucro adotada para o IRPJ. (RFB, 2016).

A alíquota da CSLL no Lucro Real é de 9\% para as pessoas jurídicas em geral, e de $15 \%$ no caso das pessoas jurídicas consideradas instituiçóes financeiras, de seguros privados e de capitalização. O seu recolhimento é trimestral.

No Lucro Presumido a CLSS é definida na Lei 10.637, de 30 de dezembro de 2002, a base de cálculo da CSLL devida por percentual de presunção da receita bruta após deduzidos as vendas canceladas e devolvidas, sendo a alíquota aplicada de $12 \%$ para as pessoas jurídicas em geral, ou a $32 \%$ no caso para as pessoas jurídicas que desenvolvam as seguintes atividades (Lei n 09.249 , de 1995, art. 20, com a redaçáo dada pela Lei n ${ }^{\circ}$ 10.684, de 2003, art. 22).

\subsubsection{COFINS - Contribuiçáo Para Financiamento Da Seguridade Social}

A COFINS veio através da Lei Complementar $n^{\circ} 70 / 91$, e seus contribuintes são as pessoas jurídicas em geral, inclusive as equiparadas, bem como as cooperativas e entidades imunes e isentas. E sua apuração é feita mensalmente.

Suas alíquotas variam de acordo o regime de tributação, no caso das empresas optantes Simples Nacional e Tributadas pelo Lucro Presumido a alíquota ser aplicada é de 3\% sobre o faturamento. As empresas optantes pelo Lucro Real é de 7,6\% sobre o faturamento.

\subsubsection{PIS - Programa De Integraçáo Social}

O PIS é calculado mensalmente sobre o faturamento, no Lucro presumido sua alíquota de $0,65 \%$, pelas pessoas jurídicas tributadas pelo Lucro Presumido, e de $1 \%$ da folha de pagamento de contribuintes tais como os templos de qualquer culto; os partidos políticos; condomínios e entidades sem fins lucrativos conforme o art. 12 da Lei no 9.532/97. As empresas tributadas pelo lucro Real são de 1,65\% do faturamento. 
De acordo com o art. $1^{\circ}$ da Lei $n^{\circ} 10$. 637, de 30 de dezembro de 2002, a contribuição para o PIS é realizada pelo faturamento mensal. Respeitando as deduçóes legais, e o aproveitamento de credito tributário no caso do não-cumulativo.

\subsubsection{ISSQN - Imposto Sobre Serviços de Qualquer Natureza}

O imposto Sobre Serviços de Qualquer Natureza é de competência dos municípios de do Distrito Federal, os índices dos serviços são instituídos na Lei Complementar 116/2003. Sáo contribuintes desse imposto a empresa ou trabalhador autônomo que presta serviços tributáveis.

O CTN (Código Tributário Nacional) traz nos artigos de 71 a 73 sobre o ISS. O imposto é cobrado toda vez que for realizado a prestação de serviço, a base de cálculo é o valor do serviço prestado, as alíquotas são definidas em lei por cada município.

\subsection{Publicaçóes de periódicos relacionados ao tema da pesquisa.}

Para realizar a pesquisa foram utilizados os termos "tributária" em conjunto com os termos "tributário" ou "tributos". Optou-se por fazer a pesquisa mais genérica possível, procurando-se fazer o filtro através da análise dos artigos. Com isto reduz-se a possibilidade de se excluir a priori trabalhos que pudessem estar relacionados ao tema, mas que não se encaixassem nos termos de pesquisa mais reduzidos.

Quando o site disponibiliza o campo "conteúdo da revista", definiu-se optar pelo item "todos", desta forma a pesquisa identifica se a palavra selecionada encontra-se em qualquer um destes setores do artigo: autor, título, resumo, termos indexados e texto completo.

A pesquisa foi realizada em revistas, para a seleção das revistas foi selecionada uma base de dados específica da área de Ciências Contábeis a Atena (portal que acessa doze periódicos científicos em Contabilidade e Gestão) e das revistas qualis A2 a seguir: Revista Contabilidade \& Finanças (RC\&F) da FEA/USP; Contabilidade Vista \& Revista da UFMG; Revista Universo Contábil da FURB/SC e Revista Brasileira de Gestão de Negócios (RBGN) da FECAP/SP.

Cabe destacar que foram encontrados diversos trabalhos direcionados à pesquisa na educação, percepçóes de profissionais, discentes e docentes, que foram desconsiderados, assim como outros trabalhos que não são direcionados a aplicação do planejamento tributário em organizaçóes privadas. Ainda, quando nos termos pesquisados surgiram o mesmo trabalho, foram considerados só uma vez.

Inicialmente na base de dados Atena foram encontrados 56 trabalhos para a palavra tributária, 17 para tributário e 17 para tributos. Após análise dos trabalhos somente seis apresentavam características relacionadas ao foco da pesquisa deste trabalho. Na Revista Brasileira de Gestão de Negócios não foi encontrado nenhum artigo relacionado ao tema. $\mathrm{Na}$ Revista Universo Contábil foram encontrados: 7 trabalhos para a palavra tributária, 9 para tributário e 3 para tributos. Após análise somente um foi relacionado com a pesquisa. Na Contabilidade Vista \& Revista foram encontrados: 2 trabalhos para a palavra tributária, 2 para tributário e nenhum para tributos. Após análise dois foram relacionados 
com a pesquisa. Finalmente, na Revista Contabilidade \& Finanças foram encontrados: 64 trabalhos para a palavra tributária, 44 para tributário e 56 para tributos. Após análise nenhum trabalho foi relacionados com a pesquisa.

Para facilitar a visualização dos trabalhos relacionados com a pesquisa, a seguir, apresenta-se o Quadro 1 com a relação dos artigos selecionados por revista. Cada artigo apresenta seu título, os autores, ano em que foi publicado e o objetivo de cada um.

\section{Quadro 1 - Artigos de Revistas}

\begin{tabular}{|c|c|c|c|}
\hline \multicolumn{4}{|l|}{ Base Atena } \\
\hline Autores & Ano & Título & Objetivo \\
\hline $\begin{array}{l}\text { Jéssica Rayse } \\
\text { de Melo Silva, } \\
\text { Lucimar Antônio } \\
\text { Cabral de Ávila, } \\
\text { Rodrigo Fernandes } \\
\text { Malaquias }\end{array}$ & 2012 & $\begin{array}{l}\text { Tipos e intensidade de } \\
\text { serviços prestados por } \\
\text { escritórios de contabilidade: } \\
\text { uma análise da prestaçáo de } \\
\text { serviços de Planejamento } \\
\text { Tributário. } \\
\end{array}$ & $\begin{array}{l}\text { identificar os tipos de serviços prestados por } \\
\text { escritórios de contabilidade, a intensidade de } \\
\text { sua prestaçáo e também aspectos ligados ao } \\
\text { planejamento tributário, inclusive analisando } \\
\text { se os serviços ofertados estáo de acordo com as } \\
\text { definiçóes da literatura adotada. }\end{array}$ \\
\hline $\begin{array}{l}\text { Marcia Corrêa } \\
\text { Ramos, Antonio } \\
\text { Lopo Martinez }\end{array}$ & 2018 & $\begin{array}{l}\text { Agressividade tributária } \\
\text { e o refazimento das } \\
\text { demonstraçōes financeiras nas } \\
\text { empresas brasileiras listadas } \\
\text { na B3. }\end{array}$ & $\begin{array}{l}\text { verificar a relação entre a agressividade tributária } \\
\text { e o refazimento das Demonstraçóes Financeiras } \\
\text { em empresas brasileiras listadas na B3. }\end{array}$ \\
\hline $\begin{array}{l}\text { Matheus Tumelero } \\
\text { Dornelles, } \\
\text { Clóvis Antônio } \\
\text { Kronbauer, João } \\
\text { Luis Peruchena } \\
\text { Thomaz, Antônio } \\
\text { Carlos Brunozi } \\
\text { Júnior } \\
\end{array}$ & 2015 & $\begin{array}{l}\text { Efeitos da adoção do regime } \\
\text { de substituição tributária do } \\
\text { ICMS na cadeia vinícola do } \\
\text { Vale dos Vinhedos }\end{array}$ & $\begin{array}{l}\text { analisou os efeitos nos preços praticados pela } \\
\text { Cadeia Vinícola do Vale dos Vinhedos em } \\
\text { funçáo da adoçáo do regime de substituiçáo } \\
\text { tributária do ICMS no período de } 2007 \text { a } 2012 .\end{array}$ \\
\hline $\begin{array}{l}\text { Bruna Altoé } \\
\text { Marques, Denizar } \\
\text { Leal, Paulo } \\
\text { Henrique Amaral } \\
\text { Rody }\end{array}$ & 2016 & $\begin{array}{l}\text { Contribuiçáo da lei do } \\
\text { bem para o planejamento } \\
\text { tributário de uma unidade } \\
\text { empresarial e a percepçáo } \\
\text { dos contadores do estado } \\
\text { do Espírito Santo sobre } \\
\text { incentivos fiscais e } \\
\text { planejamento tributário }\end{array}$ & $\begin{array}{l}\text { identificar como a Lei do Bem contribui para } \\
\text { o planejamento tributário de uma unidade } \\
\text { empresarial e qual a percepçáo dos contadores } \\
\text { do Estado do Espírito Santo sobre Incentivos } \\
\text { Fiscais e Planejamento Tributário. }\end{array}$ \\
\hline $\begin{array}{l}\text { Paulo César de } \\
\text { Melo Mendes, } \\
\text { Renan Palhares } \\
\text { Torreão Braz }\end{array}$ & 2018 & $\begin{array}{l}\text { Uma análise sobre os } \\
\text { tributos diferidos no setor de } \\
\text { Construçáo Civil }\end{array}$ & $\begin{array}{l}\text { analisar a adequação das práticas contábeis } \\
\text { apresentadas pelas entidades do setor de } \\
\text { construçấo civil às recomendaçóes doutrinárias } \\
\text { e normativas dos principais órgáos, bem como } \\
\text { o impacto, em termos numéricos, dos tributos } \\
\text { diferidos. }\end{array}$ \\
\hline
\end{tabular}




\begin{tabular}{|c|c|c|c|}
\hline $\begin{array}{l}\text { Geraldo Alemandro } \\
\text { Leite Filho, Núbia } \\
\text { Aparecida Coelho }\end{array}$ & 2002 & $\begin{array}{l}\text { Planejamento Tributário } \\
\text { pela Contabilidade: } \\
\text { uma necessidade para } \\
\text { o desenvolvimento das } \\
\text { microempresas e empresas de } \\
\text { pequeno porte Brasileiras }\end{array}$ & $\begin{array}{l}\text { demonstrar a importância, a necessidade e a } \\
\text { possibilidade de utilizaçáo do Planejamento } \\
\text { Tributário pela Contabilidade como um } \\
\text { diferencial capaz de auxiliar no desenvolvimento } \\
\text { das Microempresas (ME) e Empresas de } \\
\text { Pequeno Porte (EPP) no cenário brasileiro. }\end{array}$ \\
\hline \multicolumn{4}{|c|}{ Revista Universo Contábil } \\
\hline \begin{tabular}{|l|l} 
Autores \\
\end{tabular} & Ano & Título & Objetivo \\
\hline $\begin{array}{l}\text { Rafael Guidotti } \\
\text { Noble, Marcos } \\
\text { Antônio de Souza, } \\
\text { Lauro Brito de } \\
\text { Almeida }\end{array}$ & 2006 & $\begin{array}{l}\text { Investimentos de Capital, } \\
\text { Custo Tributário e } \\
\text { Competitividade: um caso do } \\
\text { setor Siderúrgico Brasileiro }\end{array}$ & $\begin{array}{l}\text { estudar o impacto do custo tributário incidente } \\
\text { sobre o investimento destinado à expansão de } \\
\text { uma planta siderúrgica no Brasil, comparada } \\
\text { com a carga tributária que ocorreria caso tal } \\
\text { investimento fosse realizado em outros países } \\
\text { alternativos, especificamente EUA, Canadá e } \\
\text { Chile. }\end{array}$ \\
\hline \multicolumn{4}{|c|}{ Contabilidade Vista \& Revista } \\
\hline \begin{tabular}{|l|l} 
Autores \\
\end{tabular} & Ano & \begin{tabular}{|l|} 
Título \\
\end{tabular} & Objetivo \\
\hline $\begin{array}{l}\text { Alexandre Eduardo } \\
\text { Lima Ribeiro, } \\
\text { Poueri do Carmo } \\
\text { Mário. }\end{array}$ & 2008 & $\begin{array}{l}\text { Utilizaçáo de metodologias de } \\
\text { reestruturaçáo societária como } \\
\text { ferramenta de planejamento } \\
\text { tributário: um estudo de caso }\end{array}$ & $\begin{array}{l}\text { apresentar um estudo de caso, no qual se } \\
\text { analisa a aplicabilidade das metodologias de } \\
\text { reestruturaçáo societária como ferramenta } \\
\text { de planejamento tributário em um grupo } \\
\text { empresarial do setor de agronegócio situado no } \\
\text { estado de Minas Gerais. } \\
\end{array}$ \\
\hline $\begin{array}{l}\text { Rodrigo Campolina } \\
\text { Santos, Antônio } \\
\text { Artur de Souza. }\end{array}$ & 2005 & $\begin{array}{l}\text { Planejamento Tributário: } \\
\text { o impacto dos Programas } \\
\text { Governamentais Simples e } \\
\text { Simples Geral nas micro e } \\
\text { pequenas empresas }\end{array}$ & $\begin{array}{l}\text { demonstrar como o planejamento tributário, } \\
\text { feito de forma legal e com base nestes } \\
\text { programas governamentais, pode levar às } \\
\text { MPEs fomentar o crescimento econômico } \\
\text { com o aumento da produçáo, criação de novos } \\
\text { empregos e diminuiçáo da informalidade, tudo } \\
\text { isto devido à reduçâo do ônus fiscal. }\end{array}$ \\
\hline
\end{tabular}

Fonte: Elaborado pelos autores, 2018.

Pode-se observar, o pequeno número de trabalhos que tem se realizado sob o assunto Planejamento Tributário em organizaçóes privadas nos últimos anos nos periódicos pesquisados. Este reduzido número de trabalhos, justifica a elaboração de artigos nesta área, fator fundamental em virtude da importância do tema para as organizaçóes privadas.

Verifica-se que o primeiro trabalho publicado relacionado ao planejamento tributário para microempresas e empresas de pequeno porte brasileiras foi em 2002. Posteriormente, somente em 2005 foi publicado um trabalho sob esse mesmo foco. Em 2006 e 2008 foram escritos um artigo cada ano realizando estudo de caso. Em 2012 foi analisado se os serviços contábeis envolviam o planejamento tributário. Após três anos, em 2015 foi publicado um trabalho relacionado com o assunto da pesquisa. No ano seguinte em 2016 um trabalho com o foco planejamento tributário Finalmente somente em 2018 dois artigos foram publicados que destacaram a importância deste assunto.

Todos os trabalhos selecionados destacam a importância do planejamento tributário e concordam que esta ferramenta apresenta vantagens quando implementadas pelas organizaçóes. 


\section{Metodologia da Pesquisa}

O presente trabalho foi realizado por intermédio de metodologia descritiva, documental e qualitativa (BEUREN, 2010; GIL, 2002).

O procedimento para coletar os dados foi acordado com um dos proprietários, que autorizou a disponibilidade dos demonstrativos contábeis dos períodos 2014 e 2015 e acesso as informaçóes pertinentes para a elaboração da pesquisa. O funcionário responsável por auxiliar e fornecer as informaçóes foi a pessoa encarregada do setor financeiro.

Para atingir o objetivo geral foi necessário apurar os tributos pelos três regimes disponíveis na sistemática do país: Simples Nacional, Lucro Presumido e Lucro Real. O cálculo pelo Simples Nacional não foi realizado pelos pesquisadores, pois como a empresa já utiliza este método o valor foi informado por esta, enquanto para o Lucro Presumido e Lucro Real com o auxílio de uma planilha no programa Microsoft Office Excel foram apurados os valores. Com a finalidade de observar a carga tributária em percentuais em relação à receita total para os três métodos, foram realizados as Analise Horizontal e Vertical no programa Microsoft Office Excel. Finalmente é realizada uma comparação dos resultados encontrados nas apuraçóes dos três tipos de regime tributário para verificar a diferença monetária, com a finalidade de identificar qual é o mais vantajoso.

A empresa estudada está localizada no município de Rondonópolis, no Estado de Mato Grosso. É uma sociedade empresarial Ltda. constituída apenas por pessoas físicas. Ela atua no ramo de vendas e locação de produtos de informática para empresas. Atualmente ela possui um quadro com 7 funcionários e 2 sócios. Está enquadrada no Simples Nacional, tendo em média o seu faturamento atual de aproximadamente $\mathrm{R} \$ 125.000,00$ por mês. Os dados fornecidos pela empresa foram os balaços e DRE dos anos de 2014 e 2015.

\section{Análise dos Dados}

\subsection{Apuraçáo dos Tributos pelo Simples Nacional}

A apuração do simples nacional é feita de forma unificada na Tabela 2 são apresentados os valores referentes ao faturamento da empresa. Os cálculos do simples apresentados, foram fornecidos pela empresa, os mesmos não foram recalculados devido a empresa ser optante pelo simples. 
Tabela 2 - Resultado do exercício no Simples Nacional

\begin{tabular}{l|r|r}
\hline SIMPLES NACIONAL & 2014 & 2015 \\
\hline Receita Operacional & $\mathrm{R} \$ 1.101 .960,83$ & $\mathrm{R} \$ 1.447 .617,22$ \\
\hline ( - ) Deduçóes & $\mathrm{R} \$(10.184,35)$ & $\mathrm{R} \$(1.646,99)$ \\
\hline (=) Receita Líquida & $\mathrm{R} \$ 1.093 .790,48$ & $\mathrm{R} \$ 1.447 .970,23$ \\
\hline ( - ) Custos dos Produtos Vendidos & $\mathrm{R} \$(220.657,59)$ & \\
\hline ( - ) Custos dos Serviços Prestados & $\mathrm{R} \$(32.581,66)$ & $\mathrm{R} \$(13.110,59)$ \\
\hline (=) Lucro Bruto & $\mathrm{R} \$ 840.551,23$ & $\mathrm{R} \$ 1.432 .859,64$ \\
\hline ( - ) Despesas Administrativas & $\mathrm{R} \$(322.652,16)$ & $\mathrm{R} \$(587.185,45)$ \\
\hline ( - ) Despesas Tributárias & $\mathrm{R} \$(120.210,44)$ & $\mathrm{R} \$(138.510,37)$ \\
\hline ( - ) Despesas Financeiras & $\mathrm{R} \$(43.603,23)$ & $\mathrm{R} \$(51.893,21)$ \\
\hline ( + ) Receitas Financeiras & $\mathrm{R} \$ 150,42$ & $\mathrm{R} \$ 1.387,85$ \\
\hline ( - ) Outras Despesas Operacionais & $\mathrm{R} \$(249,20)$ & $\mathrm{R} \$(822,00)$ \\
\hline (+) Outras Receitas Náo Operacionais & $\mathrm{R} \$ 353.986,62$ & $\mathrm{R} \$ 665.469,96$ \\
\hline LUCRO DO EXERCÍCIO & & 2015 \\
\hline & & 2014 \\
\hline Tributos Recolhidos & $\mathrm{R} \$ 120.210,44$ & $\mathrm{R} \$ 138.510,37$ \\
\hline Despesas Tributárias & $\mathrm{R} \$ 120.210,44$ & $\mathrm{R} \$ 138.510,37$ \\
\hline Total dos Tributos Recolhidos & & \\
\hline
\end{tabular}

Fonte: dados da pesquisa (2016).

A apuração pelo simples nacional ocorre de forma simples, não tendo muitas questôes a serem levantadas, devido à apuração dos tributos serem de forma unificada. Nota-se um crescimento tanto no faturamento quanto no lucro da empresa, para mensurar melhor os resultados abaixo na Tabela 3 apresenta-se a análise horizontal e vertical.

Tabela 3 - Análise Horizontal e Vertical no Simples Nacional

\begin{tabular}{l|r|r|r|r|r|r}
\hline SIMPLES NACIONAL & \multicolumn{1}{|c|}{2014} & $\mathrm{AH} \%$ & $\mathrm{AV} \%$ & 2015 & $\mathrm{AH} \%$ & $\mathrm{AV} \%$ \\
\hline Receita Operacional & $\mathrm{R} \$ 1.101 .960,83$ & 100 & 100 & $\mathrm{R} \$ 1.447 .617,22$ & 131,37 & 100 \\
\hline (-) Deduçóes & $\mathrm{R} \$(10.184,35)$ & 100 & 0,92 & $\mathrm{R} \$(1.646,99)$ & 16,17 & 0,11 \\
\hline (-) Receita Líquida & $\mathrm{R} \$ 1.093 .790,48$ & 100 & 99,26 & $\mathrm{R} \$ 1.445 .970,23$ & 132,20 & 99,89 \\
\hline (-) Custos dos Produtos Vendidos & $\mathrm{R} \$(220.657,59)$ & 100 & 20,02 & & 0 & 0 \\
\hline$(-)$ Custos dos Serviços Prestados & $\mathrm{R} \$(32.581,66)$ & 100 & 2,96 & $\mathrm{R} \$(13.110,59)$ & 40,24 & 0,91 \\
\hline$(=)$ Lucro Bruto & $\mathrm{R} \$ 840.551,23$ & 100 & 76,28 & $\mathrm{R} \$ 1.432 .859,64$ & 170,47 & 98,98 \\
\hline$(-)$ Despesas Administrativas & $\mathrm{R} \$(322.652,16)$ & 100 & 29,28 & $\mathrm{R} \$(578.185,45)$ & 179,20 & 3994 \\
\hline$(-)$ Despesas Tributárias & $\mathrm{R} \$(120.210,44)$ & 100 & 10,91 & $\mathrm{R} \$(138.510,37)$ & 115,22 & 9,57 \\
\hline (-) Despesas Financeiras & $\mathrm{R} \$(43.603,23)$ & 100 & 3,96 & $\mathrm{R} \$(51.893,21)$ & 119,01 & 3,58 \\
\hline (+) Receitas Financeiras & $\mathrm{R} \$ 150,42$ & 100 & 0,01 & $\mathrm{R} \$ 1.387,85$ & 922,65 & 0,10 \\
\hline (-) Outras Despesas Operacionais & $\mathrm{R} \$(249,20)$ & 100 & 0,02 & $\mathrm{R} \$(822,00)$ & 329,86 & 0,06 \\
\hline (+) Outras Receitas não Operacionais & & & & $\mathrm{R} \$ 633,50$ & 100 & 0,04 \\
\hline LUCRO DO EXERCÍCIO & $\mathrm{R} \$ 353.986,62$ & 100 & 32,12 & $\mathrm{R} \$ 665.469,96$ & 187,99 & 45,97 \\
\hline
\end{tabular}

Fonte: Elaborado pelos autores (2016). 
Pode ser observado na Tabela 3, um aumento considerável no faturamento do ano de 2015 , com um total de aproximadamente $32 \%$ a mais em relação a 2014 , o lucro da empresa teve um aumento ainda maior de aproximadamente de $46 \%$ a mais.

\subsection{Apuração dos Tributos pelo Lucro Presumido}

A apuração do Lucro Presumido é apresentada na Tabela 4, esta foi realizada com base nos dados fornecidos pela empresa e aplicado às alíquotas de presunçáo, compatível com o ramo de atividade da empresa e os serviços prestados pela mesma. Está relacionado o resultado do exercício.

Tabela 4 - Resultado do exercício no Lucro Presumido

\begin{tabular}{|c|c|c|}
\hline LUCRO PRESUMIDO & 2014 & 2015 \\
\hline Receita Operacional Bruta & $\mathrm{R} \$ 1.101 .960,83$ & $\mathrm{R} \$ 1.447 .617,22$ \\
\hline Receita de Vendas de Mercadorias & $\mathrm{R} \$ 67.638,89$ & $\mathrm{R} \$ 78.770,00$ \\
\hline Receita de Serviços & $\mathrm{R} \$ 1.034 .321,94$ & $\mathrm{R} \$ 1.368 .847,22$ \\
\hline ( - ) Deduções & $\mathrm{R} \$(10.184,35)$ & $\mathrm{R} \$(1.646,99)$ \\
\hline Deduçóes de Vendas & $\mathrm{R} \$(4.822,82)$ & $\mathrm{R} \$(1.440,00)$ \\
\hline Deduçóes de Serviços & $\mathrm{R} \$(5.361,53)$ & $\mathrm{R} \$(206,99)$ \\
\hline (=) Receita Liquida & R\$ 1.091.776,48 & R\$ $1.445 .970,23$ \\
\hline ( - ) Pis de $0,65 \%$ & $\mathrm{R} \$(7.096,55)$ & $\mathrm{R} \$(9.398,81)$ \\
\hline$(-)$ Cofins de 3\% & $\mathrm{R} \$(32.753,29)$ & $\mathrm{R} \$(43.379,11)$ \\
\hline ( - ) Iss Serviços Prestados & $\mathrm{R} \$(54.588,82)$ & $\mathrm{R} \$(72.298,51)$ \\
\hline ( - ) Custos dos Produtos Vendidos & $\mathrm{R} \$ 220.657,59)$ & \\
\hline ( - ) Custos dos Serviços Prestados & $\mathrm{R} \$(32.581,66)$ & $\mathrm{R} \$(13.110,59)$ \\
\hline (=) Lucro Bruto & $\mathrm{R} \$ 744.098,56$ & $\mathrm{R} \$ 1.307 .783,22$ \\
\hline (-)Despesas Administrativas & $\mathrm{R} \$ 322.652,16)$ & $\mathrm{R} \$(578.185,45)$ \\
\hline$(-)$ Despesas Tributarias & $\mathrm{R} \$(9.395,64)$ & $\mathrm{R} \$(20.271,35)$ \\
\hline ( - ) Despesas Financeiras & $\mathrm{R} \$(43.603,23)$ & $\mathrm{R} \$(51.893,21)$ \\
\hline (+ ) Receitas Financeiras & $\mathrm{R} \$ 150,42$ & $\mathrm{R} \$ 1.387,85$ \\
\hline$(-)$ Outras Despesas Operacionais & $\mathrm{R} \$(249,20)$ & $\mathrm{R} \$(822,00)$ \\
\hline$(+)$ Outras Receitas Não Operacionais & & $\mathrm{R} \$ 633,50$ \\
\hline ( = ) Lucro Antes do IR e CSLL & $\mathrm{R} \$ 368.348,75$ & R\$ 658.632,56 \\
\hline Presunção - IRPJ 8\% Vendas de Mercadorias & $\mathrm{R} \$ 5.025,29$ & $\mathrm{R} \$ 6.186,40$ \\
\hline Presunção - IRPJ 32\% Serviços & $\mathrm{R} \$ 329.267,33$ & $\mathrm{R} \$ 437.964,87$ \\
\hline ( = ) Presunção Total das Recceitas & $\mathrm{R} \$ 334.292,62$ & $\mathrm{R} \$ 444.151,27$ \\
\hline (+ ) Outras Receitas Totais & $\mathrm{R} \$ 150,42$ & $\mathrm{R} \$ 2.021,35$ \\
\hline ( = ) Base de Calculo IR & $\mathrm{R} \$ 334.443,04$ & $\mathrm{R} \$ 446.172,62$ \\
\hline Alíquota IRPJ - 15\% & $\mathrm{R} \$ 50.166,46$ & $\mathrm{R} \$ 66.925,89$ \\
\hline$(+)$ Adiçional $10 \%$ & $\mathrm{R} \$ 9.444,30$ & $\mathrm{R} \$ 20.617,26$ \\
\hline ( = ) IR Total & $\mathrm{R} \$ 59.610,76$ & $\mathrm{R} \$ 87.543,16$ \\
\hline Presunção - CSLL 12\% & $\mathrm{R} \$ 131.013,18$ & $\mathrm{R} \$ 173.516,43$ \\
\hline Alíquota da CSLL de $9 \%$ & $\mathrm{R} \$ 11.791,19$ & $\mathrm{R} \$ 15.616,48$ \\
\hline ( = ) Lucro Antes do IR e CSLL & $\mathrm{R} \$ 368.348,75$ & $\mathrm{R} \$$ 658.632,56 \\
\hline ( - ) IR & $\mathrm{R} \$(59.610,76)$ & $\mathrm{R} \$(87.543,16)$ \\
\hline$(-)$ CSLL & $\mathrm{R} \$(11.791,19)$ & $\mathrm{R} \$(15.616,48)$ \\
\hline LUCRO DO EXERCICIO & R\$ 296.946,81 & $\mathrm{R} \$ 555.472,92$ \\
\hline
\end{tabular}

Fonte: Elaborado pelos autores (2016). 
Verifica-se na apuração dos dados no Lucro Presumido que se a empresa fosse optante por esse tipo de tributação teria uma diminuição no seu lucro, ou seja, pagaria mais imposto em relação a apuraçáo do Simples Nacional.

Na Tabela 5 está demonstrado o total de tributos a recolher, na qual estão discriminados todos os tributos e seus respectivos valores de cada ano.

Tabela 5: Tributos a Recolher no Lucro Presumido

\begin{tabular}{l|r|r}
\hline Tributos a Recolher & $\mathbf{2 0 1 4}$ & \multicolumn{1}{c}{$\mathbf{2 0 1 5}$} \\
\hline Pis $0,65 \%$ & $\mathrm{R} \$ 7.096,55$ & $\mathrm{R} \$ 9.398,81$ \\
\hline Cofins 3\% & $\mathrm{R} \$ 32.753,29$ & $\mathrm{R} \$ 43.379,11$ \\
\hline Iss $5 \%$ & $\mathrm{R} \$ 54.588,82$ & $\mathrm{R} \$ 72.298,51$ \\
\hline Outros Tributos & $\mathrm{R} \$ 9.395,64$ & $\mathrm{R} \$ 20.271,35$ \\
\hline IR & $\mathrm{R} \$ 59.610,76$ & $\mathrm{R} \$ 87.543,16$ \\
\hline CSLL & $\mathrm{R} \$ 11.791,19$ & $\mathrm{R} \$ 15.616,48$ \\
\hline Total de Tributos & $\mathbf{R} \mathbf{1 7 5 . 2 3 6 , 2 5}$ & $\mathbf{R} \mathbf{2 4 8 . 5 0 7 , 4 2}$ \\
\hline
\end{tabular}

Fonte: Elaborado pelos autores (2016).

A Tabela 5 demonstra como a empresa ficou onerada de tributos nos dois períodos analisados; se for comparado com a receita da empresa esse valor representa aproximadamente $16 \%$ em 2014 e $17 \%$ em 2015.

Abaixo, na Tabela 6, calcula-se a análise horizontal e vertical, onde se pode verificar melhor os percentuais.

Tabela 6 - Analise Horizontal e Vertical no Lucro Presumido

\begin{tabular}{|c|c|c|c|c|c|c|}
\hline LUCRO PRESUMIDO & 2014 & AH\% & AV\% & 2015 & AH\% & AV\% \\
\hline Receita Operacional Bruta & $\mathrm{R} \$ 1.101 .960,83$ & 100 & 100 & $\mathrm{R} \$ 1.447 .617,22$ & 131,37 & 100 \\
\hline Receita de Vendas de Mercadorias & $\mathrm{R} \$ 67.638,89$ & 100 & 6,14 & $\mathrm{R} \$ 78.770,00$ & 116,46 & 5,44 \\
\hline Receita de Serviços & $\mathrm{R} \$ 1.034 .321,94$ & 100 & 93,86 & $\mathrm{R} \$ 1.368 .847,22$ & 132,34 & 94,56 \\
\hline ( - ) Deduções & $\mathrm{R} \$(10.184,35)$ & 100 & 0,92 & $\mathrm{R} \$(1.646,99)$ & 16,17 & 0,11 \\
\hline Deduçóes de Vendas & $\mathrm{R} \$(4.822,82)$ & 100 & 0,44 & $\mathrm{R} \$(1.440,00)$ & 29,86 & 0,10 \\
\hline Deduçôes de Serviços & $\mathrm{R} \$(5.361,53)$ & 100 & 0,49 & $\mathrm{R} \$(206,99)$ & 3,86 & 0,01 \\
\hline (=) Receita Liquida & R\$ 1.091.776,48 & 100 & 99,08 & R\$ 1.445.970,23 & 132,44 & 99,89 \\
\hline ( - ) Pis de $0,65 \%$ & $\mathrm{R} \$(7.096,55)$ & 100 & 0,64 & $\mathrm{R} \$(9.398,81)$ & 132,44 & 0,65 \\
\hline$(-)$ Cofins de 3\% & $\mathrm{R} \$(32.753,29)$ & 100 & 2,97 & $\mathrm{R} \$(43.379,11)$ & 132,44 & 3,00 \\
\hline ( - ) Iss Serviços Prestados & $\mathrm{R} \$(54.588,82)$ & 100 & 4,95 & $\mathrm{R} \$(72.298,51)$ & 132,44 & 4,99 \\
\hline ( - ) Custos dos Produtos Vendidos & $\mathrm{R} \$(220.657,59)$ & 100 & 20,02 & & $\mathbf{0 , 0 0}$ & 0,00 \\
\hline ( - ) Custos dos Serviços Prestados & $\mathrm{R} \$(32.581,66)$ & 100 & 2,96 & $\mathrm{R} \$(13.110,59)$ & 40,24 & 0,91 \\
\hline (=) Lucro Bruto & $\mathrm{R} \$ 744.098,56$ & 100 & 67,52 & $\mathrm{R} \$ 1.307 .783,22$ & 175,75 & 90,34 \\
\hline$(-)$ Despesas Administrativas & $\mathrm{R} \$(322.652,16)$ & 100 & 29,28 & $\mathrm{R} \$(578.185,45)$ & 179,20 & 39,94 \\
\hline ( - )Despesas Tributarias & $\mathrm{R} \$(9.395,64)$ & 100 & 0,85 & $\mathrm{R} \$(20.271,35)$ & 215,75 & 1,40 \\
\hline ( - ) Despesas Financeiras & $\mathrm{R} \$(43.603,23)$ & 100 & 3,96 & $\mathrm{R} \$(51.893,21)$ & 119,01 & 3,58 \\
\hline$(+)$ Receitas Financeiras & $\mathrm{R} \$ 150,42$ & 100 & 0,01 & $\mathrm{R} \$ 1.387,85$ & 922,65 & 0,10 \\
\hline (-) Outras Despesas Operacionais & $\mathrm{R} \$(249,20)$ & 100 & 0,02 & $\mathrm{R} \$(822,00)$ & 329,86 & 0,06 \\
\hline$(+)$ Outras Receitas Não Operacionais & & & & $\mathrm{R} \$ 633,50$ & $\mathbf{0 , 0 0}$ & 0,04 \\
\hline ( = ) Lucro Antes do IR e CSLL & $\mathrm{R} \$ 368.348,75$ & 100 & 33,43 & $\mathrm{R} \$ 658.632,56$ & 178,81 & 45,50 \\
\hline$(-)$ IR & $\mathrm{R} \$(59.610,76)$ & 100 & 5,41 & $\mathrm{R} \$(87.543,16)$ & 146,86 & 6,05 \\
\hline ( - ) CSLL & $\mathrm{R} \$(11.791,19)$ & 100 & 1,07 & $\mathrm{R} \$(15.616,48)$ & 132,44 & 1,08 \\
\hline LUCRO DO EXERCICIO & R\$ 296.946,81 & 100 & 26,95 & R\$ 555.472,92 & 187,06 & 38,37 \\
\hline
\end{tabular}

Fonte: Elaborado pelos autores (2016). 
$\mathrm{Na}$ análise vertical pode-se observar o quanto cada tributo representa em relação a receita de cada ano, diminuindo assim o lucro da empresa os tributos levam consigo boa parte do faturamento da empresa.

\subsection{Apuraçáo dos Tributos pelo Lucro Real}

Neste tópico são apresentados os cálculos pelo Lucro Real. Os dados utilizados são os fornecidos pela empresa e adequados ao regime de apuração do Lucro Real, onde são realizadas todas as deduçóes antes de apurar os impostos. Na Tabela 7 esta apresentado o resultado do exercício.

Tabela 7- Resultado do exercício no Lucro Real

\begin{tabular}{|c|c|c|}
\hline LUCRO REAL & 2014 & 2015 \\
\hline Receita Operacional Bruta & $\mathrm{R} \$ 1.101 .960,83$ & $\mathrm{R} \$ 1.447 .617,22$ \\
\hline Receita de Vendas de Mercadorias & $\mathrm{R} \$ 67.638,89$ & $\mathrm{R} \$ 78.770,00$ \\
\hline Receita de Serviços & $\mathrm{R} \$ 1.034 .321,94$ & $\mathrm{R} \$ 1.368 .847,22$ \\
\hline ( - ) Deduçóes & $\mathrm{R} \$(10.184,35)$ & $\mathrm{R} \$(1.646,99)$ \\
\hline Deduçôes de Vendas & $\mathrm{R} \$(4.822,82)$ & $\mathrm{R} \$(1.440,00)$ \\
\hline Deduçôes de Serviços & $\mathrm{R} \$(5.361,53)$ & $\mathrm{R} \$(206,99)$ \\
\hline (=) Receita Liquida & R\$ 1.091.776,48 & R\$ 1.445.970,23 \\
\hline ( - ) Pis de $1,65 \%$ & $\mathrm{R} \$(18.014,31)$ & $\mathrm{R} \$(23.858,51)$ \\
\hline ( - ) Cofins de 7,6\% & $\mathrm{R} \$(82.975,01)$ & $\mathrm{R} \$(109.893,74)$ \\
\hline ( - ) Iss Serviços Prestados 5\% & $\mathrm{R} \$(54.588,82)$ & $\mathrm{R} \$(72.298,51)$ \\
\hline ( - ) Custos dos Produtos Vendidos & $\mathrm{R} \$(220.657,59)$ & \\
\hline ( - ) Custos dos Serviços Prestados & $\mathrm{R} \$(32.581,66)$ & $\mathrm{R} \$(13.110,59)$ \\
\hline (=) Lucro Bruto & $\mathrm{R} \$ 682.959,08$ & $\mathrm{R} \$ 1.226 .808,88$ \\
\hline (-)Despesas Administrativas & $\mathrm{R} \$(322.652,16)$ & $\mathrm{R} \$(578.185,45)$ \\
\hline (-)Despesas Tributarias & $\mathrm{R} \$(9.395,64)$ & $\mathrm{R} \$(20.271,35)$ \\
\hline ( - ) Despesas Financeiras & $\mathrm{R} \$(43.603,23)$ & $\mathrm{R} \$(51.893,21)$ \\
\hline$(+)$ Receitas Financeiras & $\mathrm{R} \$ 150,42$ & $\mathrm{R} \$ 1.387,85$ \\
\hline$(-)$ Outras Despesas Operacionais & $\mathrm{R} \$(249,20)$ & $\mathrm{R} \$(822,00)$ \\
\hline (+ ) Outras Receitas Náo Operacionais & & $\mathrm{R} \$ 633,50$ \\
\hline ( = ) Lucro Antes do IR e CSLL & R\$ 307.209,27 & R\$ 577.658,22 \\
\hline ( - ) IRPJ $15 \%$ & $\mathrm{R} \$(46.081,39)$ & $\mathrm{R} \$(86.648,73)$ \\
\hline ( - ) Adicional IRPJ 10\% & $\mathrm{R} \$(6.720,93)$ & $\mathrm{R} \$(33.765,82)$ \\
\hline ( - ) CLSS & $\mathrm{R} \$(27.648,83)$ & $\mathrm{R} \$(51.989,24)$ \\
\hline LUCRO DO EXERCICIO & $\mathrm{R} \$ 226.758,12$ & R\$ 405.254,43 \\
\hline
\end{tabular}

Fonte: Elaborado pelos autores (2016).

Pode ser observado que se a empresa fosse optante pelo lucro real, iria ter um lucro bem inferior em relação à apuração pelo Simples Nacional. Ainda, seria bem menor também se comparador com o Lucro Presumido.

$\mathrm{Na}$ apuração Pis e Cofins a recolher no Lucro Real se faz o aproveitamento dos créditos de alguns custos, a Tabela 8 mostra alguns custos da empresa possíveis de tomar esses 
créditos, e também a apuração do Pis e Cofins a recolher, não foi levado em consideração os créditos de entrada de notas fiscais de compras pois não foram fornecidos os dados.

Tabela 8 - Custo que não créditos na apuração de Pis e Cofins

\begin{tabular}{l|r|r}
\hline $\begin{array}{l}\text { CUSTOS A SEREM APROVEITADOS CRÉDITOS } \\
\text { (PIS/COFINS) }\end{array}$ & $\mathbf{2 0 1 4}$ & \multicolumn{1}{c}{$\mathbf{2 0 1 5}$} \\
\hline Salários e Ordenados & $\mathrm{R} \$ 145.872,05$ & $\mathrm{R} \$ 160.915,90$ \\
\hline $13^{\circ}$ Salário & $\mathrm{R} \$ 13.987,18$ & $\mathrm{R} \$ 12.897,45$ \\
\hline Férias & $\mathrm{R} \$ 19.705,30$ & $\mathrm{R} \$ 17.954,70$ \\
\hline FGTS & $\mathrm{R} \$ 17.771,46$ & $\mathrm{R} \$ 16.191,45$ \\
\hline Energia Eletrica & $\mathrm{R} \$ 463,29$ & $\mathrm{R} \$ 12.828,61$ \\
\hline Serviços Prestados PJ & $\mathrm{R} \$ 3.910,88$ & $\mathrm{R} \$ 25.914,13$ \\
\hline Aluguel & $\mathrm{R} \$ 4.590,00$ & $\mathrm{R} \$ 16.323,10$ \\
\hline TOTAL & $\mathbf{R} \mathbf{2 0 6 . 3 0 0 , 1 6}$ & $\mathrm{R} \$ 265.040,34$ \\
\hline Crédito Pis $1,65 \%$ & $\mathrm{R} \$ 3.403,95$ & $\mathrm{R} \$ 4.373,17$ \\
\hline Crédito Cofins 7,6\% & $\mathrm{R} \$ 15.678,81$ & $\mathrm{R} \$ 20.143,07$ \\
\hline Apuraçáo de Pis & $\mathbf{2 0 1 4}$ & $\mathbf{2 0 1 5}$ \\
\hline ( = ) Pis a Recolher & $\mathrm{R} \$ 18.014,31$ & $\mathrm{R} \$ 23.858,51$ \\
\hline ( - ) Crédito de Pis & $\mathrm{R} \$(3.043,95)$ & $\mathrm{R} \$(4.373,17)$ \\
\hline ( = ) Total de Pis a Recolher & $\mathbf{R} \mathbf{1 6 . 9 8 4 , 3 6}$ & $\mathbf{R} \mathbf{2 1 . 5 0 0 , 3 4}$ \\
\hline Apuraçáo Cofins & $\mathbf{2 0 1 4}$ & $\mathbf{2 0 1 5}$ \\
\hline ( = ) Cofins a Recolher & $\mathrm{R} \$ 82.975,01$ & $\mathrm{R} \$ 109.893,74$ \\
\hline ( - ) Crédito de Cofins & $\mathrm{R} \$(15.678,81)$ & $\mathrm{R} \$(20.143,07)$ \\
\hline ( = ) Total de Cofins a Recolher & $\mathbf{R} \mathbf{6 7 . 2 9 6 , 2 0}$ & $\mathbf{R} \mathbf{8 9 . 7 5 0 , 6 7}$ \\
\hline
\end{tabular}

Fonte: Elaborado pelos autores (2016).

Conforme demonstrado na Tabela acima foi apurado o Pis na alíquota de 1,65\% e da Cofins de 7,6\%, essas alíquotas são para a apuração de tributos não-cumulativos, como é o caso do Lucro Real.

A seguir na Tabela 9 é demonstrado o total dos impostos apurados no Lucro Real: Tabela 9 - Tributos a Recolher no Lucro Real

\begin{tabular}{l|r|r}
\hline Tributos a Recolher & $\mathbf{2 0 1 4}$ & \multicolumn{1}{c}{$\mathbf{2 0 1 5}$} \\
\hline Pis $1,65 \%$ & $\mathrm{R} \$ 16.984,36$ & $\mathrm{R} \$ 21.858,51$ \\
\hline Cofins $7,6 \%$ & $\mathrm{R} \$ 67.296,20$ & $\mathrm{R} \$ 89.750,67$ \\
\hline Iss $5 \%$ & $\mathrm{R} \$ 54.588,82$ & $\mathrm{R} \$ 72.298,51$ \\
\hline Outros Tributos & $\mathrm{R} \$ 9.395,64$ & $\mathrm{R} \$ 20.271,35$ \\
\hline IR & $\mathrm{R} \$ 52.802,32$ & $\mathrm{R} \$ 120.414,55$ \\
\hline CSLL & $\mathrm{R} \$ 27.648,83$ & $\mathrm{R} \$ 51.989,24$ \\
\hline Total de Tributos & $\mathrm{R} \$ 228.716,17$ & $\mathrm{R} \$ 376.582,83$ \\
\hline
\end{tabular}

Fonte: Elaborado pelos autores (2016). 
Pode-se observar nesta Tabela 9 que se a empresa fosse optante pelo Lucro Real iria ter uma carga tributária considerável. Na Tabela 10 pode ser observado essa carga tributária em percentuais em relação à receita total.

Tabela 10 - Análise Horizontal e Vertical no Lucro Real

\begin{tabular}{|c|c|c|c|c|c|c|}
\hline LUCRO REAL & 2014 & $\mathbf{A H} \%$ & AV\% & 2015 & AH\% & AV\% \\
\hline Receita Operacional Bruta & R\$ 1.101.960,83 & 100 & 100,00 & R\$ 1.447.617,22 & 131,37 & 100,00 \\
\hline Receita de Vendas de Mercadorias & $\mathrm{R} \$ 67.638,89$ & 100 & 6,14 & $\mathrm{R} \$ 78.770,00$ & 116,46 & 5,44 \\
\hline Receita de Serviços & $\mathrm{R} \$ 1.034 .321,94$ & 100 & 93,86 & $\mathrm{R} \$ 1.368 .847,22$ & 132,34 & 94,56 \\
\hline ( - ) Deduçóes & $\mathrm{R} \$(10.184,35)$ & 100 & 0,92 & $\mathrm{R} \$(1.646,99)$ & 16,17 & 0,11 \\
\hline Deduções de Vendas & $\mathrm{R} \$(4.822,82)$ & 100 & 0,44 & $\mathrm{R} \$(1.440,00)$ & 29,86 & 0,10 \\
\hline Deduçóes de Serviços & $\mathrm{R} \$(5.361,53)$ & 100 & 0,49 & $\mathrm{R} \$(206,99)$ & 3,86 & 0,01 \\
\hline (=) Receita Liquida & R\$ 1.091.776,48 & 100 & 99,08 & R\$ 1.445.970,23 & 132,44 & 99,89 \\
\hline ( - ) Pis de $1,65 \%$ & $\mathrm{R} \$(18.014,31)$ & 100 & 1,63 & $\mathrm{R} \$(23.858,51)$ & 132,44 & 1,65 \\
\hline ( - ) Cofins de 7,6\% & $\mathrm{R} \$(82.975,01)$ & 100 & 7,53 & $\mathrm{R} \$(109.893,74)$ & 132,44 & 7,59 \\
\hline ( - ) Iss Serviços Prestados 5\% & $\mathrm{R} \$(54.588,82)$ & 100 & 4,95 & $\mathrm{R} \$(72.298,51)$ & 132,44 & 4,99 \\
\hline ( - ) Custos dos Produtos Vendidos & $\mathrm{R} \$(220.657,59)$ & 100 & 20,02 & & $\mathbf{0 , 0 0}$ & 0,00 \\
\hline ( - ) Custos dos Serviços Prestados & $\mathrm{R} \$(32.581,66)$ & 100 & 2,96 & $\mathrm{R} \$(13.110,59)$ & 40,24 & 0,91 \\
\hline (=) Lucro Bruto & $\mathrm{R} \$ 682.959,08$ & 100 & 61,98 & $\mathrm{R} \$ 1.226 .808,88$ & 179,63 & 84,75 \\
\hline ( -)Despesas Administrativas & $\mathrm{R} \$(322.652,16)$ & 100 & 29,28 & $\mathrm{R} \$(578.185,45)$ & 179,20 & 39,94 \\
\hline ( - )Despesas Tributarias & $\mathrm{R} \$(9.395,64)$ & 100 & 0,85 & $\mathrm{R} \$(20.271,35)$ & 215,75 & 1,40 \\
\hline ( - ) Despesas Financeiras & $\mathrm{R} \$(43.603,23)$ & 100 & 3,96 & $\mathrm{R} \$(51.893,21)$ & 119,01 & 3,58 \\
\hline (+ ) Receitas Financeiras & $\mathrm{R} \$ 150,42$ & 100 & 0,01 & $\mathrm{R} \$ 1.387,85$ & 922,65 & 0,10 \\
\hline ( - ) Outras Despesas Operacionais & $\mathrm{R} \$(249,20)$ & 100 & 0,02 & $\mathrm{R} \$(822,00)$ & 329,86 & 0,06 \\
\hline ( + ) Outras Receitas Não Operacionais & & & 0,00 & $\mathrm{R} \$ 633,50$ & $\mathbf{0 , 0 0}$ & 0,04 \\
\hline ( = ) Lucro Antes do IR e CSLL & R\$ 307.209,27 & 100 & 27,88 & $\mathrm{R} \$ 577.658,22$ & 188,03 & 39,90 \\
\hline ( - ) IRPJ $15 \%$ & $\mathrm{R} \$(46.081,39)$ & 100 & 4,18 & $\mathrm{R} \$(86.648,73)$ & 188,03 & 5,99 \\
\hline ( - ) Adicional IRPJ 10\% & $\mathrm{R} \$(6.720,93)$ & 100 & 0,61 & $\mathrm{R} \$(33.765,82)$ & 502,40 & 2,33 \\
\hline ( - ) CLSS & $\mathrm{R} \$(27.648,83)$ & 100 & 2,51 & $\mathrm{R} \$(51.989,24)$ & 188,03 & 3,59 \\
\hline LUCRO DO EXERCICIO & R\$ 226.758,12 & 100 & 20,58 & $\mathrm{R} \$ 405.254,43$ & 178,72 & 27,99 \\
\hline
\end{tabular}

Fonte: Elaborado pelos autores (2016).

Observando em termos percentuais, os tributos em relação à receita da empresa, nota-se que em 2014 eles representam aproximadamente 23\% em 2014 e 28\% em 2015, ou seja, esse é um valor recolhido pela empresa para os cofres públicos que poderiam ser destinados a outros objetivos.

\subsection{Comparação dos tributos}

Neste tópico é realizada uma comparação dos resultados na apuração dos três tipos de regime tributário A Tabela 11 mostra um compara dos tributos a recolher pelos regimes do simples nacional em relação ao Lucro Presumido. 
Tabela 11 - Comparativo Simples Nacional X Lucro Presumido

\begin{tabular}{l|r|r|r}
\hline \multicolumn{1}{c|}{ Comparativo dos Tributos } & \multicolumn{1}{c|}{ Simples } & \multicolumn{1}{c}{ Lucro Presumido } & \multicolumn{1}{c}{ Diferença } \\
\hline $\mathbf{2 0 1 4}$ & $\mathrm{R} \$ 120.210,44$ & $\mathrm{R} \$ 175.236,25$ & $\mathrm{R} \$ 55.025,81$ \\
\hline $\mathbf{2 0 1 5}$ & $\mathrm{R} \$ 138.510,37$ & $\mathrm{R} \$ 248.507,42$ & $\mathrm{R} \$ 109.997,05$ \\
\hline
\end{tabular}

Fonte: Elaborado pelos autores (2016).

Pode ser observado que no simples nacional a empresa poupou em 2014 um total de $\mathrm{R}$ \$ 55.025,81 aproximadamente 32\% em relação à apuração do presumido e em 2015 uma economia maior ainda de $\mathrm{R} \$ 109.997,05$ cerca de aproximadamente 44\%.

A seguir demonstra-se graficamente as diferenças dos valores destes tributos entre os regimes Simples e Lucro Presumido na Figura 1.

Figura 1 - Comparativo dos Tributos a Recolher: Simples X Lucro Presumido

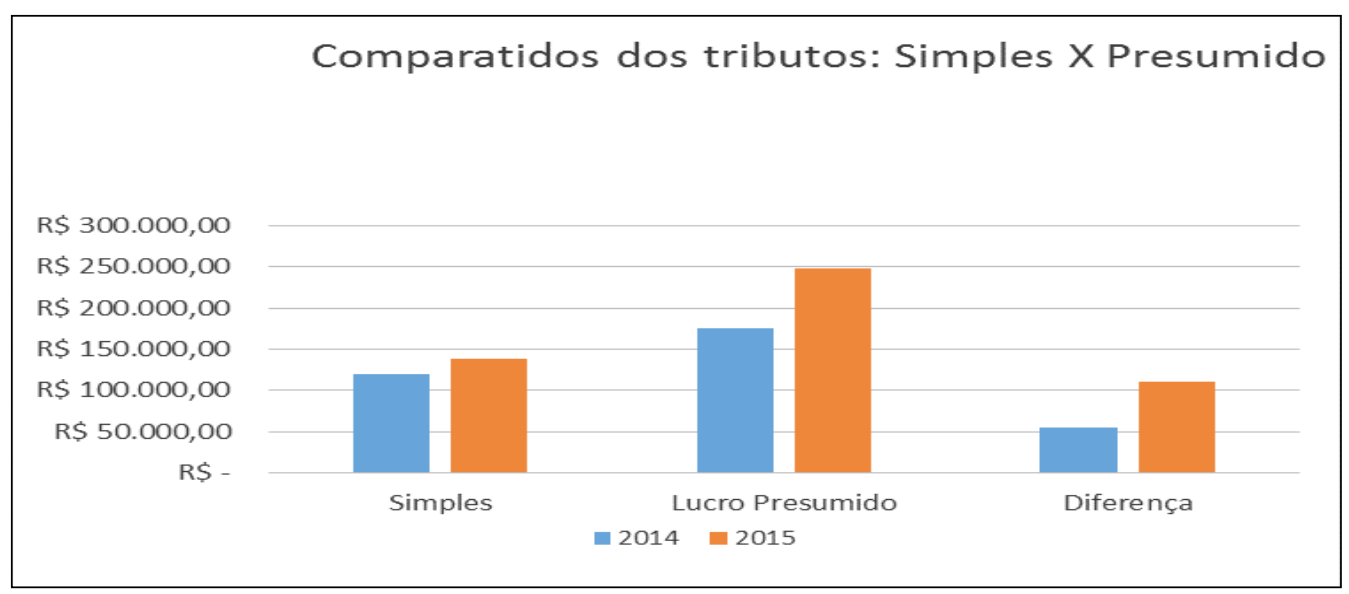

Fonte: Elaborada pelos autores (2016)

Observa-se (Figura 1) que a empresa economizou um valor bem considerável estando no regime do Simples Nacional.

A seguir, na Tabela 12, é demonstrado um comparativo do Simples Nacional com o Lucro real:

Tabela 12 - Comparativo Simples Nacional X Lucro Real

\begin{tabular}{l|l|l|l}
\hline \multicolumn{1}{c|}{ Comparativo dos Tributos } & \multicolumn{1}{c|}{ Simples } & Lucro Real & Diferença \\
\hline $\mathbf{2 0 1 4}$ & $\mathrm{R} \$ 120.210,44$ & $\mathrm{R} \$ 228.716,17$ & $\mathrm{R} \$ 108.505,73$ \\
\hline $\mathbf{2 0 1 5}$ & $\mathrm{R} \$ 138.510,37$ & $\mathrm{R} \$ 376.582,83$ & $\mathrm{R} \$ 238.072,46$ \\
\hline
\end{tabular}

Fonte: Elaborado pelos autores (2016).

Conforme demonstrado na Tabela 12 fica evidente que o Lucro Real é o regime menos apropriado para a empresa em questão. No ano de 2014, se ela estivesse no Lucro 
Real pagaria quase o dobro em tributos, sua opçấo fez poupar aproximadamente $47 \%$. Enquanto em 2015 ela iria pagar mais que o dobro do valor que foi pago pelo Simples, essa economia chegou a aproximadamente 63\%. Na Figura 2 se apresenta o gráfico com esse resultado.

Figura 2 - Comparativo dos Tributos a Recolher: Simples X Lucro Real

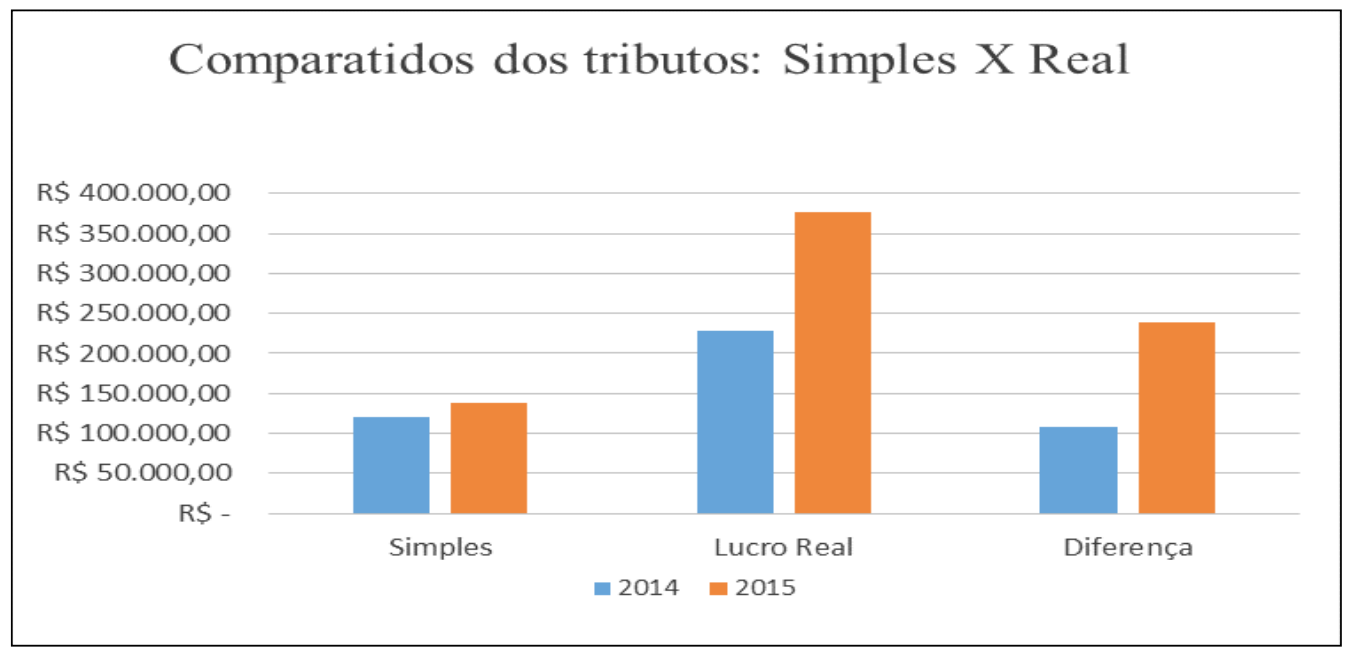

Fonte: Elaborada pelos autores (2016)

Conforme a Figura 2 observa-se uma diferença significante dos tributos a recolher de acordo com os dois regimes de apuração em questão, sendo notado que o mais vantajoso é o simples nacional.

Analisando os comparativos dos impostos a recolher dos regimes de tributação podese verificar que o regime do Simples Nacional, no qual a empresa já se enquadra é o mais vantajoso, devido ao fato da empresa ser de pequeno porte e ter um baixo custo operacional.

\section{CONSIDERAÇÓES FINAIS}

$\mathrm{O}$ presente estudo pesquisou o planejamento tributário da empresa objeto. O foco do estudo recai sobre os principais tipos de tributação: Simples Nacional, Lucro Real e Lucro Presumido. O planejamento tributário se torna importante na medida em que a empresa se preocupa com o recolhimento de tributos e quer poupar o seu próprio bolso.

Em relação aos objetivos, foram levantados os dados da empresa por meios de relatórios contábeis os balanços e a DRE dos anos de 2014 e 2015 realizados os cálculos pelo Simples Nacional, Lucro Presumido e Lucro Real. Verificados os impostos incidentes nos três regimes de tributação. Através dos resultados realizados verificou-se que a empresa já está na melhor opção tributaria, quando comparado os cálculos do simples com os demais tipos, foi visto uma economia considerável.

Fazendo uma relação dos tributos a recolher pode ser observado que no simples nacional a empresa poupou em 2014 um total de $\mathrm{R} \$ 55.025,81$ aproximadamente $32 \%$ em 
relação a apuração do presumido e em 2015 uma economia maior ainda de $\mathrm{R}$ \$ 109.997,05 aproximadamente $44 \%$. Se comparando o Lucro Real, a diferença é ainda maior no ano de 2014 e se ela estivesse no Lucro Real pagaria quase o dobro em tributos poupando aproximadamente $47 \%$ a mais e em 2015 ela iria pagar 63\% a mais.

Sugere-se que a empresa faça essa análise pelo menos de dois em dois anos, para verificar se o simples continua sendo a melhor maneira de tributação.

Como desdobramentos futuros, nessa linha de pesquisa propóem-se: (i) analisar as pesquisas realizadas com outras empresas do mesmo ramo, (ii) analisar outros ramos de atividades, (iii) verificar outras formas de fazer a verificar qual a melhor tributação para as empresas, e (iv) analisar se existem muitas publicaçóes desse cunho em outros cursos.

\section{REFERENCIAS}

BEUREN, Ilse Maria. Como elaborar trabalhos monográficos em contabilidade: teoria e prática. 3.ed. São Paulo: Atlas, 2010.

BRASIL. CODIGO TRIBUTÁRIO NACIONAL. 24 ed. Rio de Janeiro: Saraiva, 2010.

BRASIL. Decreto no 3.000 de 24 de maio de 2006. Regulamenta a tributaçáo, fiscalização, arrecadação e administração do Imposto sobre a Renda e Proventos de Qualquer Natureza. Diário Oficial (da República Federativa do Brasil), Brasília, 26 de março de 1999.

BRASIL. Lei Complementar $\mathbf{n}^{\circ}$ 70, de 30 de dezembro de 1991. Institui contribuição para financiamento da Seguridade Social, eleva a alíquota da contribuição social sobre o lucro das instituiçóes financeiras e dá outras providências. Diário Oficial (da República Federativa do Brasil). Brasília, 30 de dezembro de 1991.

BRASIL. Lei Complementar no 116, de 31 de julho de 2003. Dispóe sobre o Imposto Sobre Serviços de Qualquer Natureza, de competência dos Municípios e do Distrito Federal, e dá outras providências. Diário Oficial (da República Federativa do Brasil). Brasília, 31 de julho de 2003.

BRASIL. Lei Complementar no 123, de 14 de dezembro de 2006. Institui o Estatuto Nacional da Microempresa e da Empresa de Pequeno Porte; altera dispositivos das Leis no 8.212 e 8.213, ambas de 24 de julho de 1991, da Consolidação das Leis do Trabalho CLT, aprovada pelo Decreto-Lei no 5.452, de 1o de maio de 1943, da Lei no 10.189, de 14 de fevereiro de 2001, da Lei Complementar no 63, de 11 de janeiro de 1990; e revoga as Leis no 9.317, de 5 de dezembro de 1996, e 9.841, de 5 de outubro de 1999. Diário Oficial (da República Federativa do Brasil). Brasília, 14 de dezembro de 2006.

BRASIL. Lei no 10.637, de 30 de dezembro de 2002. Dispóe sobre a não-cumulatividade na cobrança da contribuição para os Programas de Integração Social (PIS) e de Formação do Patrimônio do Servidor Público (Pasep), nos casos que especifica; sobre o pagamento 
e o parcelamento de débitos tributários federais, a compensação de créditos fiscais, a declaração de inaptidão de inscrição de pessoas jurídicas, a legislação aduaneira, e dá outras providências. Diário Oficial (da República Federativa do Brasil). Brasília, 30 de dezembro de 2002.

BRASIL. Lei no 10.684, de 30 de maio de 2003. Altera a legislação tributária, dispóe sobre parcelamento de débitos junto à Secretaria da Receita Federal, à Procuradoria-Geral da Fazenda Nacional e ao Instituto Nacional do Seguro Social e dá outras providências. Diário Oficial (da República Federativa do Brasil). Brasília, 30 de maio de 2003.

BRASIL. Lei no $\mathbf{1 2 . 8 1 4}$ de 16 de maio de 2013.. Altera a Lei no 12.096, de 24 de novembro de 2009, quanto à autorização para concessão de subvenção econômica em operaçôes de financiamento destinadas a aquisição e produção de bens de capital e a inovação tecnológica e em projetos de infraestrutura logística direcionados a obras de rodovias e ferrovias objeto de concessão pelo Governo federal; altera a Lei no 11.529, de 22 de outubro de 2007, quanto à concessão de subvenção econômica em operaçóes destinadas a financiamentos a diferentes setores da economia; altera a Lei no 12.409 , de 25 de maio de 2011, quanto à concessáo de subvenção econômica em financiamentos destinados a beneficiários localizados em Municípios atingidos por desastres naturais; altera as Leis nos 12.487, de 15 de setembro de 2011, 9.718, de 27 de novembro de 1998, e 11.491, de 20 de julho de 2007; prorroga os prazos previstos nas Leis nos 12.249, de 11 de junho de 2010, e 11.941, de 27 de maio de 2009. Diário Oficial (da República Federativa do Brasil. Brasília, 16 de maio de 2013.

BRASIL. Lei no 5.172, de 25 de outubro de 1966. CTN. Dispóe sobre o Sistema Tributário Nacional e institui normas gerais de direito tributário aplicáveis à União, Estados e Municípios. Diário Oficial (da República Federativa do Brasil). Brasília, 25 de outubro de 1966.

BRASIL. Lei No 9.249, de 26 de Dezembro de 1995. Altera a legislação do imposto de renda das pessoas jurídicas, bem como da contribuição social sobre o lucro líquido, e dá outras providências. Diário Oficial (da República Federativa do Brasil). Brasília, 26 de dezembro de 1995.

BRASIL. Lei no 9.430, de 27 de dezembro de 1996. Dispóe sobre a legislação tributária federal, as contribuiçóes para a seguridade social, o processo administrativo de consulta e dá outras providências. Diário Oficial (da República Federativa do Brasil), Brasília, 27 de dezembro de 1996.

BRASIL. Lei no 9.718, de novembro de 1998. Altera a Legislação Tributária Federal. Diário Oficial (da República Federativa do Brasil), Brasília, 27 de novembro de 1998.

CHAVES, Francisco Coutinho. Planejamento Tributário na Prática: Gestão Tributária Aplicada. 4.ed. São Paulo: Atlas, 2017. 
DORNELLES, M.; KRONBAUER, C.; PERUCHENA THOMAZ, J.; JÚNIOR, A.. Efeitos da adoção do regime de substituição tributária do ICMS na cadeia vinícola do Vale dos Vinhedos. Revista Ambiente Contábil. Universidade Federal do Rio Grande do Norte, América do Norte, 7, jun. 2015.

FABRETTI, Láudio Camargo. Contabilidade Tributária. 11. ed. São Paulo: Editora Atlas, 2009.

FABRETTI, Láudio Camargo. Contabilidade tributária. 14. ed. São Paulo: Atlas, 2014.

GIL, Antônio Carlos. Como elaborar projetos de pesquisa. 4. ed. - São Paulo : Atlas, 2002.

GOLLUB, Ediana Hermann. Planejamento Tributário: Estudo de Caso de uma empresa do Ramo do Agronegócio. Trabalho de Conclusão de Curso apresentado ao curso de Ciências Contábeis, da Universidade Regional do Noroeste do Estado do Rio Grande do Sul (UNIJUÍ), 2015.

GUIDOTTI NOBLE, Rafael; DE SOUZA, Marcos Antônio; BRITO DE ALMEIDA, Lauro. Investimentos de capital, custo tributário e competitividade: um caso do setor siderúrgico brasileiro. Revista Universo Contábil, [S.1.], v. 2, n. 2, p. 24-36, jul. 2007.

LEITE FILHO, Geraldo Alemandro; COELHO, Núbia Aparecida. Planejamento Tributário pela Contabilidade: uma necessidade para o desenvolvimento das Microempresas e Empresas de Pequeno Porte brasileiras. Pensar Contábil, Vol. 5, No 17, 2002.

MARQUES, B., LEAL, D., RODY, P.. Contribuição da Lei do Bem para o planejamento tributário de uma unidade empresarial e a percepçáo dos contadores do Estado do Espírito Santo sobre incentivos fiscais e planejamento tributário. Revista Ambiente Contábil. Universidade Federal do Rio Grande do Norte, América do Norte, 8, abr. 2016.

MAXIMIANO, Antonio Cesar Amaru. Administração para empreendedores: fundamento da criação e da gestão de novos negócios. 2.ed. São Paulo: Pearson, 2011.

MENDES, P., BRAZ, R.. Uma análise sobre os tributos diferidos no setor de construção civil. Revista Ambiente Contábil. Universidade Federal do Rio Grande do Norte, América do Norte, 10, jun. 2018.

MUNIZ, Humberto. Planejamento Tribuitário como Ferramenta para Reduçáo de Impostos. 2012. Disponível em: <http://www.contabeis.com.br/artigos/708/ planejamento-tribuitario-como-ferramenta-para-reducao-de-impostos/>. Acesso em 12 out. 2016.

OLIVEIRA, Gustavo P. Contabilidade tributária. 3. ed. São Paulo: Saraiva. 2009. 
RAMOS, M. C.; MARTINEZ, A. L. Agressividade Tributária e o Refazimento das Demonstrações Financeiras nas Empresas Brasileiras Listadas na B3. Pensar Contábil, v. 20, n. 72, p. 4-15, 2018.

RECEITA Federal do Brasil. Tributos federais administrados pela Secretaria da Receita Federal do Brasil. Disponível em: <https://idg.receita.fazenda.gov.br/acesso-rapido/ tributos>. Acesso em: 12 Dez. 2016.

RIBEIRO, A. E. L.; MÁRIO, P. C. Utilização de metodologias de reestruturação societária como ferramenta de planejamento tributário: um estudo de caso.

Contabilidade Vista \& Revista, v. 19, n. 4, p. 107-128, 2008.

SANTOS, Thiago Rocha dos. A contabilidade e o planejamento estratégico. 2012. Disponível em: <http:/www.contabeis.com.br/artigos/960/a-contabilidade-e-oplanejamento-estrategico/>. Acesso em: 12 out. 2016.

SANTOS, R. C.; SOUZA, A. A. Planejamento Tributário: o impacto dos Programas Governamentais Simples e Simples Geral nas micro e pequenas empresas. Contabilidade Vista \& Revista, v. 16, n. 1, p. 73-88, 2005.

SILVA, J., DE ÁVILA, L., MALAQUIAS, R.. Tipos e intensidade de serviços prestados por escritórios de contabilidade: uma análise da prestação de serviços de planejamento tributário. Revista de Contabilidade do Mestrado em Ciências Contábeis da UERJ, América do Norte, 17, jan. 2013.

SILVA, Flaviane Aparecida de Oliveira et al. A importância do planejamento tributário nas empresas mediante a complexa carga tributária brasileira. Janus, Lorena, n.13, Jan./ Jun., 2011. p. 011-027.

ZANLUCA, Júlio Cézar. Planejamento tributário: pague menos, dentro da lei! Brasileiro paga dezenas de tributos! 2012. Disponível em: <http://www.portaltributario.com.br/ planejamento.htm>. Acesso em: 27 jul 2016. 